\title{
Modeling chemical and aerosol processes in the transition from closed to open cells during VOCALS-REx
}

\author{
J. Kazil ${ }^{1,2}$, H. Wang ${ }^{3}$, G. Feingold ${ }^{2,1}$, A. D. Clarke ${ }^{4}$, J. R. Snider ${ }^{5}$, and A. R. Bandy ${ }^{6}$ \\ ${ }^{1}$ Cooperative Institute for Research in Environmental Sciences (CIRES), University of Colorado, Boulder, CO, USA \\ ${ }^{2}$ NOAA Earth System Research Laboratory, Chemical Sciences Division, Boulder, CO, USA \\ ${ }^{3}$ Pacific Northwest National Laboratory, Atmospheric Sciences \& Global Change Division, Richland, WA, USA \\ ${ }^{4}$ School of Ocean and Earth Science and Technology, University of Hawaii, Honolulu, HI, USA \\ ${ }^{5}$ Department of Atmospheric Science, University of Wyoming, Laramie, WY, USA \\ ${ }^{6}$ Chemistry Department, Drexel University, Philadelphia, PA, USA
}

Received: 18 January 2011 - Published in Atmos. Chem. Phys. Discuss.: 9 February 2011

Revised: 14 June 2011 - Accepted: 4 July 2011 - Published: 1 August 2011

\begin{abstract}
Chemical and aerosol processes in the transition from closed- to open-cell circulation in the remote, cloudy marine boundary layer are explored. It has previously been shown that precipitation can initiate a transition from the closed- to the open-cellular state, but that the boundary layer cannot maintain this open-cell state without a resupply of cloud condensation nuclei (CCN). Potential sources of CCN include wind-driven production of sea salt from the ocean, nucleation from the gas phase, and entrainment from the free troposphere. In order to investigate $\mathrm{CCN}$ sources in the marine boundary layer and their role in supplying new particles, we have coupled in detail chemical, aerosol, and cloud processes in the WRF/Chem model, and added state-of-the-art representations of sea salt emissions and aerosol nucleation. We conduct numerical simulations of the marine boundary layer in the transition from a closed- to an open-cell state. Results are compared with observations in the Southeast Pacific boundary layer during the VAMOS Ocean-CloudAtmosphere-Land Study Regional Experiment (VOCALS$\mathrm{REx})$. The transition from the closed- to the open-cell state generates conditions that are conducive to nucleation by forming a cloud-scavenged, ultra-clean layer below the inversion base. Open cell updrafts loft dimethyl sulfide from the ocean surface into the ultra-clean layer, where it is oxidized during daytime to $\mathrm{SO}_{2}$ and subsequently to $\mathrm{H}_{2} \mathrm{SO}_{4}$. Low $\mathrm{H}_{2} \mathrm{SO}_{4}$ condensation sink values in the ultra-clean layer allow $\mathrm{H}_{2} \mathrm{SO}_{4}$ to rise to concentrations at which aerosol nu-
\end{abstract}

Correspondence to: J. Kazil (jan.kazil@noaa.gov) cleation produces new aerosol in significant numbers. The existence of the ultra-clean layer is confirmed by observations. We find that the observed DMS flux from the ocean in the VOCALS-REx region can support a nucleation source of aerosol in open cells that exceeds sea salt emissions in terms of the number of particles produced. The freshly nucleated, nanometer-sized aerosol particles need, however, time to grow to sizes large enough to act as CCN. In contrast, mechanical production of particles from the ocean surface by near-surface winds provides a steady source of larger particles that are effective $\mathrm{CCN}$ at a rate exceeding a threshold for maintenance of open-cell circulation. Entrainment of aerosol from the free troposphere contributes significantly to boundary layer aerosol for the considered VOCALS-REx case, but less than sea salt aerosol emissions.

\section{Motivation}

The cloudy marine boundary layer (MBL) is of much interest from a climate system perspective. Bright, reflective clouds overlaying a dark ocean surface exert significant shortwave cooling with no appreciable compensation in the longwave. Moreover, atmospheric aerosol is known to modify the brightness of these shallow, warm-phase clouds; increases in the aerosol result in more reflective clouds, ceteris paribus (Twomey, 1977). The aerosol also modifies the ability of clouds to precipitate, with implications for cloud cover and lifetime (Warner, 1968; Albrecht, 1989).

Early satellite imagery and aerial photography yielded dramatic evidence of mesoscale organization of cloud systems

Published by Copernicus Publications on behalf of the European Geosciences Union. 
in the form of rolls and hexagonal patterns, with clear analogy to Rayleigh-Bénard convection (Agee, 1984). The cloud systems tend to organize into mesoscale cellular convective states that exhibit closed or open cellular structures (Stevens et al., 2005a; Wang and Feingold, 2009). Closed-cell circulation is characterized by high cloud fraction and relatively low drizzle amounts. The circulation is driven by cloudtop radiative cooling resulting in narrow, stronger downdrafts that flank broader regions of weaker updrafts. In contrast, over warm water with strong surface forcing, an open-cell state with broad, cloud-free regions surrounded by narrow, strong updraft regions is the preferred state. Within closedcell regions, pockets of open cells (POCs) may form. POCs are characterized by vigorous updrafts and optically thick, strongly precipitating clouds in the open cell walls, and optically thin clouds in the cell interiors. Precipitation is thought to be a necessary (Stevens et al., 2005a) but not sufficient (Wood et al., 2010) condition for the transition from closed to open cells, which introduces the possibility that MBL aerosol, via its influence on precipitation, can play a role in determining the dynamical state and self-organization of the system. If precipitation is strong enough, and the MBL is sufficiently depleted in cloud condensation nuclei $(\mathrm{CCN}$, aerosol particles which activate to cloud droplets) the MBL is no longer able to sustain itself; convective circulation weakens and clouds disappear (Ackerman et al., 1993). Wang et al. (2010) showed in a case study of the Southeast Pacific stratocumulus deck that replenishment of accumulation mode particles at the rate of $\sim 1 \mathrm{~cm}^{-3} \mathrm{~h}^{-1}$, uniformly distributed over the depth of the boundary layer, was sufficient to maintain an open-cell circulation. The aerosol sources can be emissions of particles from the ocean, entrainment of aerosol from the free troposphere, and nucleation from the gas phase.

Oceanic emissions and entrainment from the free troposphere are thought to account for commonly observed aerosol concentrations in the MBL (Katoshevski et al., 1999; Clarke et al., 2006). At the same time, aerosol nucleation has been found to occur infrequently in the marine boundary layer (Heintzenberg et al., 2004), as sulfuric acid $\left(\mathrm{H}_{2} \mathrm{SO}_{4}\right)$, an efficient nucleation agent, is quickly removed from the gas phase by sea salt particles and water droplets. However, strong relationships between concentrations of oceanemitted dimethyl sulfide (DMS) and marine aerosol concentrations have been observed (Ayers and Gras, 1991; Andreae et al., 1995; Clarke et al., 1998), supporting nucleation as a source of aerosol in the marine environment. Capaldo et al. (1999) investigated nucleation of $\mathrm{H}_{2} \mathrm{SO}_{4}$ from DMS oxidation in the MBL with a model of aerosol and chemical processes with prescribed clouds and precipitation. In their study, nucleation occurred at the top of the boundary layer after precipitation or entrainment of clean air from the free troposphere reduced the aerosol surface area. They concluded that nucleation may be an important, but not a dominant source of aerosol in the MBL. More recently, Petters et al. (2006) and Tomlinson et al. (2007) observed enhanced concentrations of small Aitken mode particles under conditions of reduced aerosol surface area in open cells, and explained these with nucleation in the MBL: strong precipitation in open cells removes pre-existing aerosol particles, aerosol surface area, and reduces the sulfuric acid condensation sink (Kulmala et al., 2001) to values that are sufficiently small to allow accumulation of gas phase $\mathrm{H}_{2} \mathrm{SO}_{4}$ to concentrations at which nucleation becomes efficient.

Hence in open cells, oceanic emissions of DMS, which is oxidized in the gas phase by the hydroxyl $(\mathrm{OH})$ and nitrate $\left(\mathrm{NO}_{3}\right)$ radicals to sulfur dioxide $\left(\mathrm{SO}_{2}\right)$ (Ravishankara et al., 1997), and the latter subsequently to $\mathrm{H}_{2} \mathrm{SO}_{4}$, could result in the formation of new aerosol by nucleation, and provide $\mathrm{CCN}$ for the maintenance of the open-cell circulation, in addition to $\mathrm{CCN}$ emitted from the ocean and entrained from the free troposphere. Open-cell regions are therefore potential candidates for the CLAW hypothesis (Charlson et al., 1987), which proposes that in broken cloud situations ocean phytoplankton respond to the increased surface (solar) radiation and temperature by producing more DMS, which in turn, results in stronger aerosol nucleation in the MBL, an increased number of aerosol particles, and a higher cloud albedo/fraction. This constitutes a negative feedback loop, since it was the lower cloud fraction and higher surface radiation that helped generate the particles in the first place.

The strength of MBL aerosol sources will be determined by various factors: oceanic emissions of DMS, which provide the gas phase precursor molecules for nucleation and growth of aerosol particles, depend on near-surface wind speeds and seawater DMS concentrations (e.g. Huebert et al., 2004, and references therein). Sea salt emissions are driven by near-surface wind as well, and while providing new CCN, suppress aerosol nucleation by increasing the sink for nucleating molecules. Entrainment of aerosol from the free troposphere depends on the strength of the inversion, and on the presence of enhanced aerosol concentrations above it, e.g. from long-range transport of pollution.

To study the role of aerosol sources in supplying new particles in this complex, interactive system, we have coupled in detail chemical, aerosol, and cloud processes in the WRF/Chem model (Grell et al., 2005), and added representations of primary oceanic emissions (Clarke et al., 2006) and of aerosol nucleation from the gas phase (Kazil et al., 2010). In this work we introduce the new features of the model, investigate chemical and aerosol processes in the transition from closed to open cells, and evaluate the ability of the model to reproduce chemical and aerosol measurements in open cells during the VAMOS Ocean-Cloud-AtmosphereLand Study Regional Experiment (VOCALS-REx) (Wood et al., 2011). The role of boundary layer dynamics for chemical processing of DMS and as a driver of aerosol nucleation is discussed in detail, and nucleation, ocean emissions, and entrainment as sources of new aerosol for the specific case of open cells during VOCALS-REx are compared. 


\section{Model}

We use the Advanced Research Weather Research and Forecasting (ARW; v3.1.1) model (Skamarock et al., 2008), building on the work of Wang and Feingold (2009), who incorporated an improved two-moment warm-rain microphysical scheme originally developed by Feingold et al. (1998) in the ARW, as well as a high-order monotonic advection scheme (Wang et al., 2009) to better represent aerosol-cloudprecipitation interactions. We operate the ARW model with interactive chemistry and aerosol microphysics (WRF/Chem, Grell et al., 2005), which has been coupled with the twomoment cloud microphysics scheme. In addition, we have added emissions of sea salt particles as parameterized by Clarke et al. (2006), and neutral and charged nucleation of sulfuric acid and water following Kazil et al. (2010).

\subsection{Coupling of chemical, aerosol, and cloud processes}

We have extended the two-moment cloud microphysics scheme (Feingold et al., 1998) to treat the number and mass of aerosol particles contained in cloud and rain droplets, as well as the mass of chemical species dissolved in cloud and rain water, and coupled it to the WRF/Chem twomoment aerosol module MADE (Modal Aerosol Dynamics Model for Europe, Ackermann et al., 1998), and to the WRF/Chem aqueous chemistry scheme (Fahey and Pandis, 2001), described in Sects. 2.3 and 2.4. The cloud microphysics scheme calculates the number of newly-formed cloud droplets from the MADE aerosol size distribution consisting of an Aitken, accumulation and coarse mode and integrates the equations for condensation and evaporation of cloud and rain droplets, as well as those for droplet collision-coalescence and sedimentation. In the course of these processes, the number and mass of aerosol particles residing in cloud and rain droplets, and the mass of chemical species dissolved in cloud and rain water are treated as well-mixed, passive species; changes in their concentrations resulting from microphysics are calculated based on the relative changes calculated for the host cloud and rain droplets. For example, dissolved matter is released to the gas phase from cloud and rain droplets in proportion to the evaporated water mass. Mass transfer of gas and aerosol species between cloud and rain water due to collision-coalescence or condensation/evaporation is scaled by the mass transfer of cloud and rain water. Evaporation of cloud water leads to the regeneration of interstitial aerosol once the mixing ratio of cloud water falls below a given threshold. Based on observations, each evaporating droplet can be assumed to produce a single aerosol particle (Mitra et al., 1992; Feingold et al., 1996) which means that at any given moment the droplet concentration is equivalent to the potential number of particles that can be regenerated as aerosol. Thus, if the microphysics scheme determines a reduction in cloud (rain) droplet number concentration based on collision-coalescence, the num- ber of aerosol particles residing in cloud (rain) water is reduced by the same amount. This treatment implies that aerosol particles inside coalescing droplets merge.

Particulate and dissolved matter in cloud and rain water is resolved in the cloud microphysics scheme by chemical species, and in the case of particulate matter also by the three aerosol modes (Aitken, accumulation, coarse) of the MADE aerosol scheme. In the present implementation, it is assumed that the growth of cloud-borne Aitken mode particles resulting from collision-coalescence of droplets and from aqueous chemistry will produce accumulation mode particles upon evaporation of the droplets. On completion of the cloud microphysics calculations, activated Aitken mode particles are therefore placed in the accumulation mode. This treatment of mode transfer due to cloud processing is based on the notion that it is activation in the first place which is responsible for the emergence of the accumulation mode, hence being activated is a sensible criterion that a particle should belong to the accumulation mode. Sensitivity to this assumption was examined by Feingold et al. (1996). Activated accumulation and coarse mode particles remain in their respective modes upon completion of the cloud microphysics calculations.

The treatment of the aerosol processing by clouds described here follows that by Feingold et al. (1996) and Feingold and Kreidenweis (2002), and reproduces the same essential features as the more detailed calculations of Flossmann et al. (1985). Further details on the coupling between chemical, aerosol, and cloud processes used in this work are given in Appendix A.

\subsection{Gas phase chemistry and radiation}

Our simulations apply the gas phase chemical mechanism originally developed by Stockwell et al. (1990) for the Regional Acid Deposition Model version 2 (RADM2, Chang et al., 1989), which is implemented in WRF/Chem with the Kinetic Pre-Processor (Damian et al., 2002). In order to enable the computationally demanding simulations, the chemical scheme has been simplified by removing nonmethane hydrocarbons and their reactions. The ubiquitous methane has been retained in the chemical scheme, as it may contribute to ozone formation via reactions involving $\mathrm{NO}_{\mathrm{x}}$. However, given the very low $\mathrm{NO}_{\mathrm{x}}$ levels during the VOCALS-REx campaign that are indicated by the low observed $\mathrm{CO}$ and supported by calculations by Yang et al. (2009), we expect a negligible contribution to ozone formation from the oxidation of methane and other volatile organic compounds. To account for the effect of oceanic sulfur emissions on MBL processes, the oxidation of DMS by $\mathrm{OH}$ and $\mathrm{NO}_{3}$, which produces $\mathrm{SO}_{2}$, was added. The list of gas phase species and their reactions are given in Appendices B and C, respectively.

Long- and shortwave radiative transfer is treated with the CAM (Community Atmosphere Model, Collins et al., 2004) scheme. Molecular photolysis frequencies are calculated 
with the Tropospheric Ultraviolet and Visible (TUV) Radiation Model (Madronich and Flocke, 1999); the photochemical reactions used in this work are given in Appendix D.

\subsection{Aerosol microphysics}

We use the WRF/Chem two-moment aerosol module MADE (Modal Aerosol Dynamics Model for Europe, Ackermann et al., 1998) to treat aerosol microphysical processes. MADE describes the aerosol size distribution with three log-normal modes (Aitken, accumulation and coarse) with fixed geometric standard deviations $(1.4,1.5$, and 2.0 , in our simulations, respectively). The number of particles and the mass of the chemical compounds $\left(\mathrm{SO}_{4}^{2-}, \mathrm{NH}_{4}^{+}, \mathrm{NO}_{3}^{-}, \mathrm{Na}^{+}\right.$, and $\mathrm{Cl}^{-}$in this work) in each aerosol mode, for both interstitial aerosol and aerosol residing in liquid water (sum of cloud and rain water) are tracked in WRF/Chem as prognostic variables. Throughout this work we refer to interstitial aerosol particles when these are neither enclosed in cloud nor rain water.

Partitioning of sulfate, ammonium, nitrate, and water between aerosol and the gas phase is calculated in equilibrium as described by Grell et al. (2005), for all three aerosol modes. The effect of aerosol $\mathrm{Na}^{+}$and $\mathrm{Cl}^{-}$on the partitioning is not considered in the calculation, which may result in an underestimation of aerosol water content and sulfuric acid condensation sink of the aerosol modes (see Sect. 4.3). The aerosol $\mathrm{H}_{2} \mathrm{SO}_{4}$ condensation sink (Kulmala et al., 2001) determines removal of sulfuric acid from the gas phase at cloud-free locations; we use the numerical scheme described in Kokkola et al. (2009) to integrate the resulting prognostic equation. At cloudy locations, all gas phase $\mathrm{H}_{2} \mathrm{SO}_{4}$ is removed instantaneously and converted to aerosol sulfate residing in liquid water.

\subsection{Aqueous chemistry}

Partitioning of the gas phase species into cloud and rain water and their conversion to aerosol species has been implemented in WRF/Chem by Chapman et al. (2009) using the bulk aqueous chemistry scheme of Fahey and Pandis (2001), which solves the prognostic equations for the vapor pressures and liquid phase concentrations of the involved species. Aqueous chemistry proceeds for the Aitken and the accumulation mode contained in cloud and rain water, but not for the coarse mode. This simplification can be motivated by the consideration that conversion of gas phase to aerosol mass via aqueous chemistry depends on the volume of liquid water associated with each aerosol mode, which is proportional to the number of activated particles from a given aerosol mode. In typical conditions, the Aitken and accumulation modes supply the majority of activated particles. In our implementation, transfer of particles from the Aitken to the accumulation mode in the liquid phase via growth due to aqueous chemistry is not treated by the aqueous chemistry scheme as in Chapman et al. (2009), but by the cloud microphysical scheme (see Sect. 2.1).

\subsection{Aerosol nucleation}

The formation of aerosol particles from the gas phase is implemented with the scheme described in Kazil et al. (2010): the scheme accounts for neutral and charged $\mathrm{H}_{2} \mathrm{SO}_{4} / \mathrm{H}_{2} \mathrm{O}$ nucleation based on thermochemical parameters (entropy and enthalpy change) for the uptake and loss of $\mathrm{H}_{2} \mathrm{SO}_{4}$ and $\mathrm{H}_{2} \mathrm{O}$ molecules by small neutral and negatively charged $\mathrm{H}_{2} \mathrm{SO}_{4} / \mathrm{H}_{2} \mathrm{O}$ clusters, measured in the laboratory (Curtius et al., 2001; Froyd and Lovejoy, 2003; Hanson and Lovejoy, 2006). These thermochemical data were used in the method of Kazil and Lovejoy (2007) to generate a table of steadystate formation rates of neutral and charged $\mathrm{H}_{2} \mathrm{SO}_{4} / \mathrm{H}_{2} \mathrm{O}$ particles with $15 \mathrm{H}_{2} \mathrm{SO}_{4}$ molecules, as a function of temperature, relative humidity, gas phase sulfuric acid concentration, $\mathrm{H}_{2} \mathrm{SO}_{4}$ condensation sink onto pre-existing aerosol, and ionization rate. The table is interpolated in $\mathrm{WRF} / \mathrm{Chem}$ to obtain the particle formation rate at given ambient conditions. The formation rate of atmospheric ions, which drive charged nucleation, is calculated as a function of atmospheric mass column density, vertical cutoff rigidity, and solar cycle phase as described in Kazil et al. (2010).

The number and mass of particles formed by nucleation are committed to the MADE Aitken mode at cloud-free locations. At cloudy locations, all sulfuric acid is removed from the gas phase and apportioned as sulfate to the aerosol particles residing in cloud and rain water. The number and mass of the nucleating particles and of the pre-existing Aitken mode particles are conserved as aerosol from nucleation is placed in the Aitken mode, but no discrete nucleation mode can form alongside the Aitken mode in the course of nucleation in this approach. This simplification is viable in the conditions considered in this work: in the pristine MBL, sulfur dioxide and sulfuric acid gas phase concentrations are low, and pre-existing aerosol needs to be strongly depleted for nucleation to occur. This is e.g. the case when cloud processes have scavenged particles down to the critical diameter for activation, leaving a depleted Aitken mode with a smaller geometric mean diameter, which is used to accommodate aerosol from nucleation. This simplification is supported by observations of Petters et al. (2006) in the Northeast Pacific MBL and by Tomlinson et al. (2007) in the Southeast Pacific MBL, which show a pronounced, single dominant mode of small aerosol particles, which likely formed by nucleation as a result of depletion of larger particles. In polluted conditions, where nucleation may occur in the presence of non-negligible concentrations of pre-existing aerosol in the Aitken, accumulation, or coarse mode, this simplification would not be able to capture the features of the aerosol size distribution during and after a nucleation event, when distinct nucleation and Aitken modes may be present concurrently. The addition of a dedicated nucleation mode 

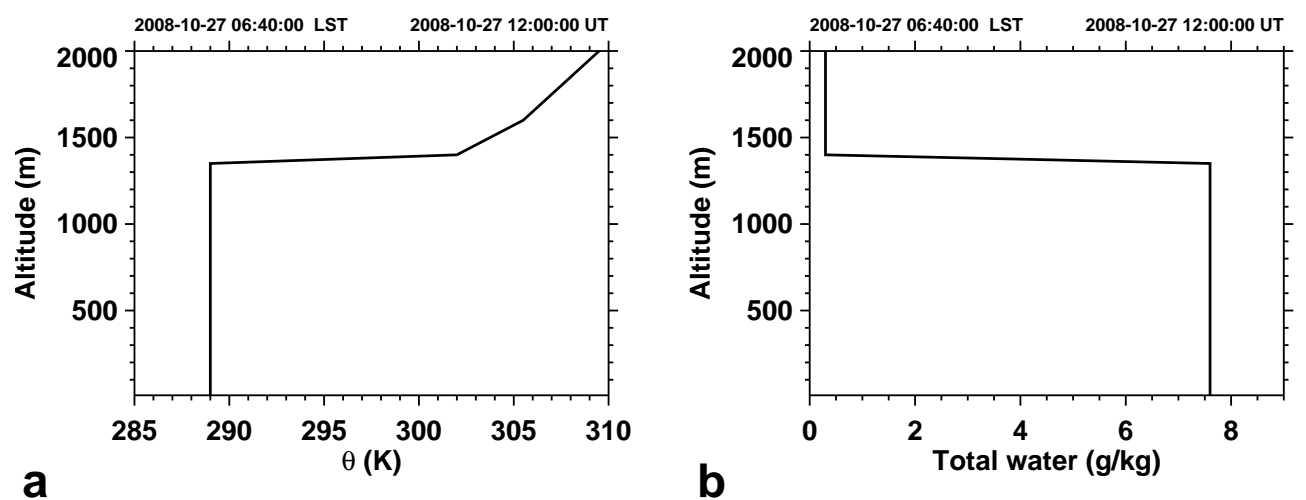

Fig. 1. Initial vertical profiles of (a) potential temperature and (b) total water mixing ratio, present as water vapor at the start of the simulations.

in the WRF/Chem MADE aerosol scheme is planned for the future.

\subsection{Ocean sources and sinks}

The sea salt aerosol flux from the ocean is described with the size-resolved parameterization by Clarke et al. (2006), which covers particles in the (dry) diameter range from $10 \mathrm{~nm}$ to $8 \mu \mathrm{m}$. We prescribe sea salt as a mixture of $\mathrm{Na}^{+}, \mathrm{Cl}^{-}$, and $\mathrm{SO}_{4}^{2-}$, with the respective mass fractions $0.330,0.593$, and 0.077 (DOE, 1994), with a total mass density of $2.2 \mathrm{~g} \mathrm{~cm}^{-3}$ (Lewis and Schwartz, 2004). The number and mass of sea salt particles entering the three modes of the WRF/Chem aerosol module MADE is calculated by splitting the sizeresolved sea salt particle flux at $100 \mathrm{~nm}$ and $1 \mu \mathrm{m}$ into Aitken, accumulation, and coarse mode particles. The aerosol particles emitted from the ocean surface are placed into the lowermost model layer. The whitecap fraction is parameterized with the expression of Monahan et al. (1986) as a function of wind speed at $10 \mathrm{~m}$ above the ocean surface. Ocean emissions of DMS are based on measurements during VOCALSREx (Yang et al., 2009).

Dry deposition of gas phase species onto the ocean surface is represented in WRF/Chem with the method of Wesely (2007). However, observations suggest that current parameterizations overestimate dry deposition: Faloona et al. (2010) found an average dry deposition velocity of $\mathrm{SO}_{2}$ in the (cloud-free) MBL that was about $30 \%$ lower than calculated with an approach related to that of WRF/Chem. Similarly, Gray et al. (2010) concluded from analysis of observations that current (global) models may significantly overestimate $\mathrm{SO}_{2}$ dry deposition rates over some tropical marine areas. Although in the cloud-free MBL, dry deposition is the second most important loss process of $\mathrm{SO}_{2}$ after loss onto aerosol (Faloona et al., 2010), in the cloud-capped MBL during VOCALS-REx, the strongest loss process of $\mathrm{SO}_{2}$ was aqueous oxidation, and dry deposition only a minor sink (Yang et al., 2011). Dry deposition of gas phase species is therefore disabled in the simulations for this work. Dry deposition of aerosol particles is disabled as well, as it is treated together with parameterized sub-grid turbulent mixing and aerosol activation in WRF/Chem, which cannot be operated together with the cloud microphysics scheme used in our simulations (Wang and Feingold, 2009; Feingold et al., 1998).

\section{Simulations}

The simulations in this work build on those of Wang et al. (2010). The simulation domain is centered around $80^{\circ} \mathrm{W}$, $20^{\circ} \mathrm{S}$, extending $60 \times 60 \mathrm{~km}^{2}$ horizontally and $2 \mathrm{~km}$ vertically. The horizontal (vertical) grid spacing is $300(30) \mathrm{m}$, and the time step $3 \mathrm{~s}$. The domain size and resolution were chosen to accommodate a boundary layer dynamic structure with several open cells, under consideration of the high numerical burden arising from the treatment of chemical and aerosol processes in addition to cloud processes. The horizontal resolution is coarser than in typical boundary layer large eddy simulations, and its appropriateness has been discussed in Wang and Feingold (2009). Cyclic boundary conditions are used in both horizontal dimensions.

The simulations are initialized with meteorological profiles based on VOCALS-REx RF06 soundings (Wang et al., 2010; Wood et al., 2010). Figure 1 shows the initial profiles of potential temperature and total water, present as water vapor at the start of the simulations. These initial conditions correspond to the "dry" initial profiles used in Wang et al. (2010). A large scale wind field with velocities of $-6 \mathrm{~m} \mathrm{~s}^{-1}$ in the west-east and $7 \mathrm{~m} \mathrm{~s}^{-1}$ in the south-north directions are used throughout the domain. A sensible surface heat flux of $15 \mathrm{~W} \mathrm{~m}^{-2}$ and a latent surface heat flux of $122 \mathrm{~W} \mathrm{~m}^{-2}$ are used, together with a large scale surface divergence of $1.67 \times 10^{-6} \mathrm{~s}^{-1}$, based on VOCALS-REx RF06 observations inside a POC region (Wang et al., 2010; Wood et al., 2010). 

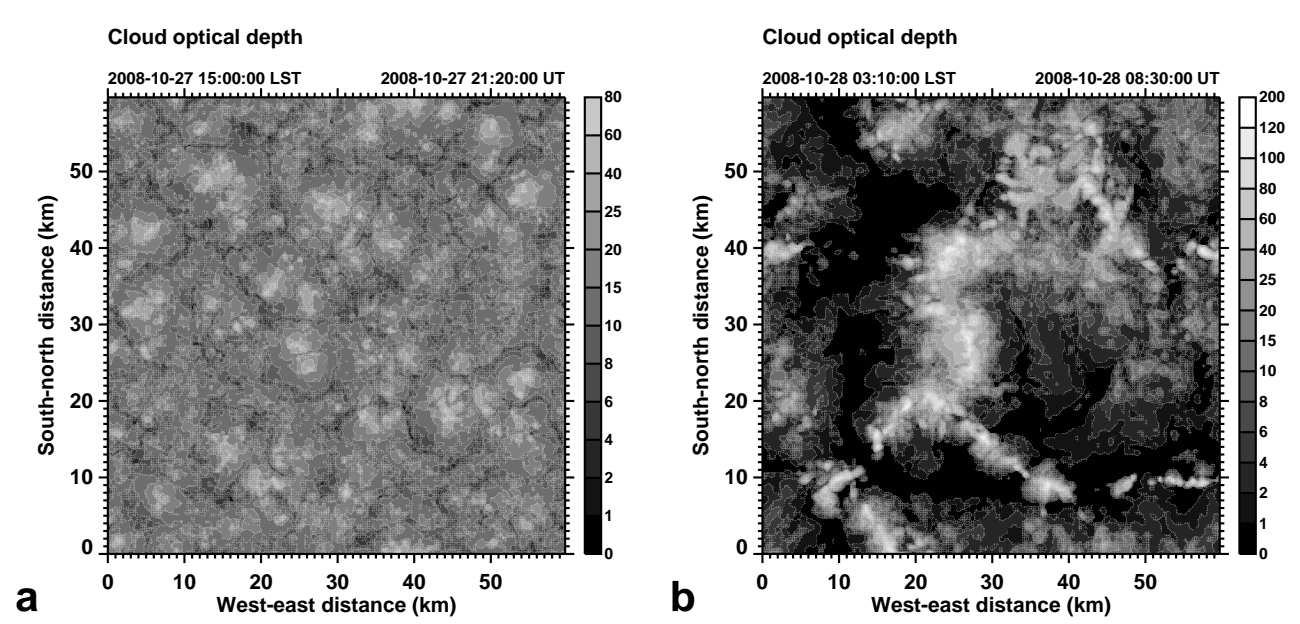

Fig. 2. Cloud optical depth in simulation $\mathcal{S}_{0}$. Initially, the cloud field exhibits high optical depths in cell centers and reduced optical depths along the cell peripheries, characteristic of closed-cell circulation (a). Approximately $12 \mathrm{~h}$ later, the cloud field has developed open-cell circulation with high optical depths along the cell peripheries, and reduced optical depths in the cell centers (b).

Table 1. Initial aerosol properties in the marine boundary layer (MBL) and free troposphere (FT).

\begin{tabular}{lll}
\hline & MBL & FT \\
\hline Aitken mode concentration & 0 & $150 \mathrm{mg}^{-1}$ \\
Aitken mode geom. mean dry diameter & - & $30 \mathrm{~nm}^{-1}$ \\
& & \\
Accumulation mode concentration & $95 \mathrm{mg}^{-1}$ & $135 \mathrm{mg}^{-1}$ \\
Accumulation mode geom. mean dry diameter & $200 \mathrm{~nm}$ & $200 \mathrm{~nm}$ \\
Coarse mode concentration & 0 & 0 \\
Coarse mode geom. mean dry diameter & - & - \\
\hline
\end{tabular}

Initial aerosol mode concentrations and sizes in the marine boundary layer and free troposphere were derived from measurements during VOCALS-REx RF06 (Wood et al., 2010) and are given in Table 1 . The coarse mode is initialized with a zero number concentration, as is the Aitken mode in the boundary layer. Sea salt emissions provide Aitken, accumulation, and coarse mode particles, and nucleation provides Aitken mode particles as the simulation progresses. The initial composition of Aitken mode particles is pure sulfuric acid, while initial accumulation mode particles are composed of sea salt (Sect. 2.6). Initial values of trace gas species are given in Table 2. Ozone and carbon monoxide are initialized based on VOCALS-REx RF06 measurements. Initial $\mathrm{H}_{2} \mathrm{O}_{2}$ is estimated based on observations in the mid-latitude eastern Pacific reported in O'Sullivan et al. (2004). $\mathrm{CO}_{2}$ and $\mathrm{CH}_{4}$ are typical background values for the current epoch (NOAA AGGI, 2010), while $\mathrm{SO}_{2}$ and DMS are initialized with ad hoc estimates of these compounds $24 \mathrm{~h}$ prior to RF06. Trace gas species not listed in Table 2 are initialized with zero mixing ratios.
Table 2. Initial trace gas composition of the simulations $\mathcal{S}_{0}$ and $\mathcal{S}_{1}$. Trace gas species not listed here are initialized with zero values. Initial values of $\mathcal{S}_{1}$ are given in parentheses where they differ from $\mathcal{S}_{0}$.

\begin{tabular}{lll}
\hline & Boundary layer & Free troposphere \\
\hline $\mathrm{CO}_{2}$ & $380 \mathrm{ppm}$ & $380 \mathrm{ppm}$ \\
$\mathrm{CH}_{4}$ & $1.7 \mathrm{ppm}$ & $1.7 \mathrm{ppm}$ \\
$\mathrm{CO}$ & $64 \mathrm{ppb}$ & $70 \mathrm{ppb}$ \\
$\mathrm{O}_{3}$ & $30 \mathrm{ppb}$ & $55 \mathrm{ppb}$ \\
$\mathrm{HO}_{2}$ & $0 \mathrm{ppt}$ & $0.1 \mathrm{ppt}$ \\
$\mathrm{H}_{2} \mathrm{O}_{2}$ & $500 \mathrm{ppt}$ & $500 \mathrm{ppt}$ \\
$\mathrm{DMS}$ & $60(25) \mathrm{ppt}$ & $0 \mathrm{ppt}$ \\
$\mathrm{SO}_{2}$ & $40(25) \mathrm{ppt}$ & $10 \mathrm{ppt}$ \\
\hline
\end{tabular}

Two simulations $\left(\mathcal{S}_{0}, \mathcal{S}_{1}\right)$ are conducted which differ in the DMS flux from the ocean: in $\mathcal{S}_{0}$, the DMS flux is set to $4.8 \mu \mathrm{mol} \mathrm{m} \mathrm{m}^{-2} \mathrm{~d}^{-1}$ based on the average flux from shipboard measurements during VOCALS-REx at $80^{\circ} \mathrm{W}, 20^{\circ} \mathrm{S}$ (Yang et al., 2009). In simulation $\mathcal{S}_{1}$, the DMS flux is reduced by a factor of 0.5 , which will produce DMS profiles that are more consistent with the RF06 aircraft measurements than the original shipboard flux. The simulations commence at 12:00 UT on 27 October 2008, approximately $24 \mathrm{~h}$ before VOCALS-REx RF06 (Wood et al., 2010), and continue for another $24 \mathrm{~h}$ thereafter. Sunset and sunrise occur at 00:00 UT and 10:40 UT, respectively. The conversion between universal time (UT) and local solar time (LST) for the location of the simulations is LST $=\mathrm{UT}-05: 20 \mathrm{~min}$. During the first $1 \mathrm{~h}$ of the simulations, chemical and aerosol processes, ocean emissions, as well as sedimentation and collisioncoalescence of cloud and rain droplets are disabled in order to 
a

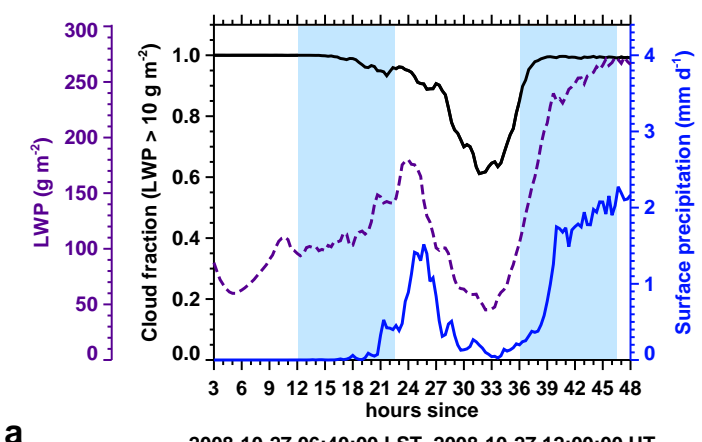

2008-10-27 06:40:00 LST 2008-10-27 12:00:00 UT
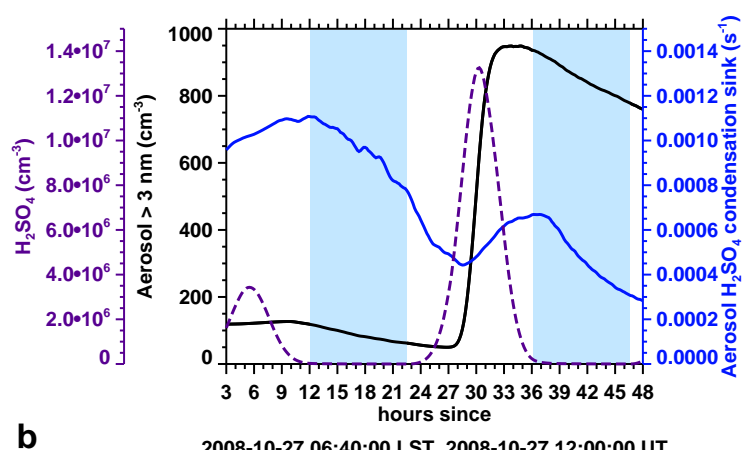

2008-10-27 06:40:00 LST 2008-10-27 12:00:00 UT

Fig. 3. Time series from simulation $\mathcal{S}_{0}$ of (a) domain-averaged liquid water path, cloud fraction, and precipitation, and of (b) gas phase sulfuric acid concentration, concentration of aerosol particles larger than $3 \mathrm{~nm}$ in dry diameter, and aerosol sulfuric acid condensation sink, averaged over cloud-free locations in the boundary layer. Light blue shading indicates nighttime.

allow for the formation of a turbulent cloudy boundary layer with the associated cloud top cooling that drives the MBL circulation.

\section{Results}

\subsection{Transition from closed to open cells and aerosol nucleation}

Trajectory calculations and satellite imagery indicate that the MBL sampled in VOCALS-REx RF06 experienced a transition from closed- to open-cell circulation approximately in the $12 \mathrm{~h}$ preceding the RF06 measurements (Wood et al., 2010). The transition is characterized by a progression from an overcast cloud deck with a comparably homogeneous optical depth to a broken cloud with optically thick clouds along the open cell boundaries, and optically thin clouds in the cell centers. The transition and the associated change in cloud structure in the simulations is illustrated in Fig. 2: in the afternoon of the first day, simulation $\mathcal{S}_{0}$ exhibits a cloud field with high optical depths in cell centers and reduced optical depths along the cell peripheries (Fig. 2a), characteristic of closed cells. Approximately $12 \mathrm{~h}$ later, in the second half of the night, the cloud structure has developed an open-cell pattern with high optical depths along the cell peripheries, and reduced optical depths in the cell centers (Fig. 2b). Peak optical depths have increased in the course of the transition from about 60 to 120, owing to the stronger but more localized convection in open cells walls.

Figure 3a shows the evolution of liquid water path (LWP), cloud fraction, and precipitation in simulation $\mathcal{S}_{0}$. The liquid water path exhibits daytime minima due to solar heating and evaporation, but in the afternoon, as solar irradiation wanes, it recovers and grows until the next morning. This accumulation of liquid water accelerates conversion of cloud to rain droplets by collision-coalescence, which initiates precipitation during the first night. The onset of precipitation breaks up cloud cover, and the cloud fraction decreases into the fol- lowing day, initially due to significant forenoon precipitation, and later, as precipitation levels off, due to heating by solar radiation. In the late afternoon, with lessened solar heating, it recuperates and reaches unity early in the following night.

Figure $3 \mathrm{~b}$ shows time series of aerosol $\mathrm{H}_{2} \mathrm{SO}_{4}$ condensation sink, gas phase $\mathrm{H}_{2} \mathrm{SO}_{4}$ concentration, and aerosol particles $>3 \mathrm{~nm}$ in (dry) diameter, averaged over cloud-free location of the MBL during simulation $\mathcal{S}_{0}$. Together with the time series in Fig. 3a, it provides information on chemical and aerosol processes taking place in the transition from the closed- to the open-cell state. The aerosol $\mathrm{H}_{2} \mathrm{SO}_{4}$ condensation sink is, with a lag, anticorrelated with LWP, and to a lesser extent with precipitation. The responsible processes are collision-coalescence and wet removal: collisioncoalescence and the resulting merging of aerosol particles inside cloud droplets proceeds more rapidly with increasing LWP, which leads to a decrease in aerosol surface area and therefore aerosol $\mathrm{H}_{2} \mathrm{SO}_{4}$ condensation sink. Precipitation transports aerosol particles to the ocean surface, and thereby leads to an additional reduction in aerosol $\mathrm{H}_{2} \mathrm{SO}_{4}$ condensation sink. At reduced $\mathrm{H}_{2} \mathrm{SO}_{4}$ condensation sink values, photochemically produced $\mathrm{H}_{2} \mathrm{SO}_{4}$ can accumulate to higher concentrations. As a result, a $\mathrm{H}_{2} \mathrm{SO}_{4}$ peak occurs during the first daytime period, when the MBL is in closed-cell circulation, followed by a larger peak during the second daytime period, when it is in open-cell circulation (Fig. 3b). However, the aerosol $\mathrm{H}_{2} \mathrm{SO}_{4}$ condensation sink is only one factor determining the $\mathrm{H}_{2} \mathrm{SO}_{4}$ concentration - photochemical production and loss by condensation onto cloud and rain droplets contribute as well. The overcast cloud deck associated with closed-cell circulation limits photochemical production of $\mathrm{H}_{2} \mathrm{SO}_{4}$ during the first daytime period by limiting the solar flux in the MBL, and by uptake of $\mathrm{SO}_{2}$ and $\mathrm{H}_{2} \mathrm{SO}_{4}$ onto cloud and rain droplets. During the second daytime period, when the MBL is in open-cell mode, the reduced cloud liquid water and optical depth in the cell centers allows faster photochemical production of $\mathrm{H}_{2} \mathrm{SO}_{4}$, while loss of $\mathrm{SO}_{2}$ and $\mathrm{H}_{2} \mathrm{SO}_{4}$ onto hydrometeors proceeds more slowly. 


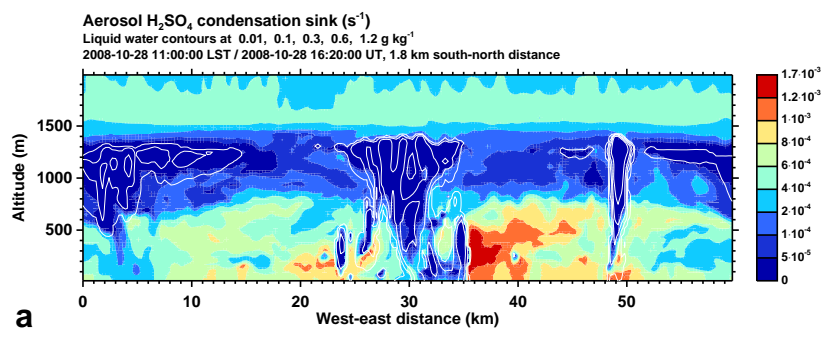

a

DMS (ppt)

Liquid water contours at $0.01,0.1,0.3,0.6,1.2 \mathrm{~g} \mathrm{~kg}$

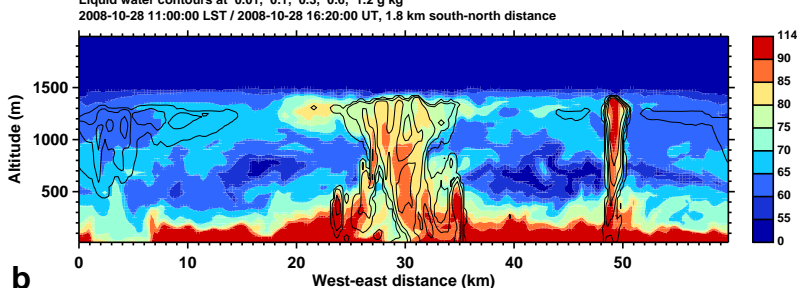

b

${ }^{20}$ West-east distance $(\mathrm{km})$

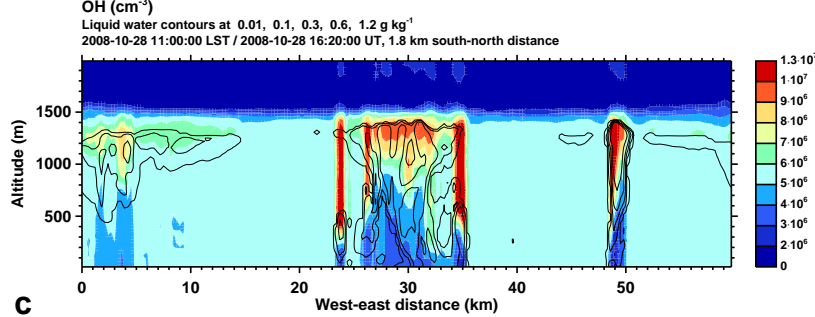

C

West-east distance $(\mathrm{km})$

Fig. 4. Vertical slices through the domain of simulation $\mathcal{S}_{0}$ at 28 October 2008 16:20 UT. Contour lines denote liquid water (sum of cloud and rain water). (a) Cloud processes in open cell updrafts deplete aerosol particles and reduce the aerosol $\mathrm{H}_{2} \mathrm{SO}_{4}$ condensation sink, which is lowest inside clouds. The clean, cloud-processed air detrains in the upper boundary layer and forms an ultra-clean layer with low aerosol $\mathrm{H}_{2} \mathrm{SO}_{4}$ condensation sink values. (b) Updrafts lift DMS emitted from the ocean into the upper boundary layer. (c) Scattering of solar radiation around cloud tops results in elevated $\mathrm{OH}$ concentrations, which oxidize DMS to $\mathrm{SO}_{2}$.

The resulting higher $\mathrm{H}_{2} \mathrm{SO}_{4}$ concentration in the second daytime period initiates aerosol nucleation from the gas phase, which manifests itself in the formation of aerosol particles $>3 \mathrm{~nm}$ in (dry) diameter (Fig. 3b).

The mechanisms discussed in this section are illustrated in detail in Figs. 4 and 5, which show vertical slices through the domain of simulation $\mathcal{S}_{0}$ at 28 October 2008 16:20 UT. Liquid water mixing ratio (sum of cloud and rain water), associated with convective updrafts along open cell walls, is denoted by contour lines. For reference in the following discussion, the liquid water mixing ratio is shown with the residual wind velocity, which excludes the large scale wind field, in Fig. 6.

The slices in Figs. 4 and 5, and 6 cut through three cloudy regions of open cell boundaries: a decaying convective zone in the west, a region of broad convection in the center, and a localized convective updraft in the east. Scavenging by collision-coalescence and drizzle in the updrafts depletes aerosol particles. As a result, air detraining from the updrafts

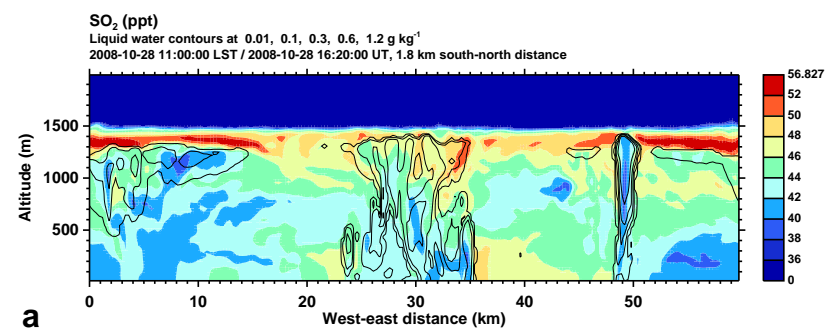

a

$\mathrm{H}_{2} \mathrm{SO}_{4}\left(\mathrm{~cm}^{-3}\right)$

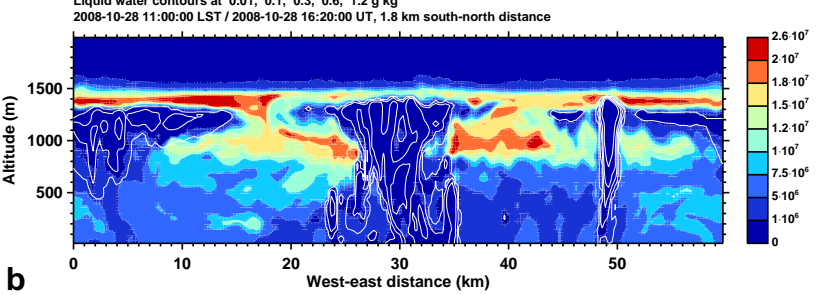

b

Formation rate of particles with $15 \mathrm{H}_{2} \mathrm{SO}_{4}$ molecules from nucleation $\left(\mathrm{cm}^{-3} \mathrm{~s}^{-1}\right)$

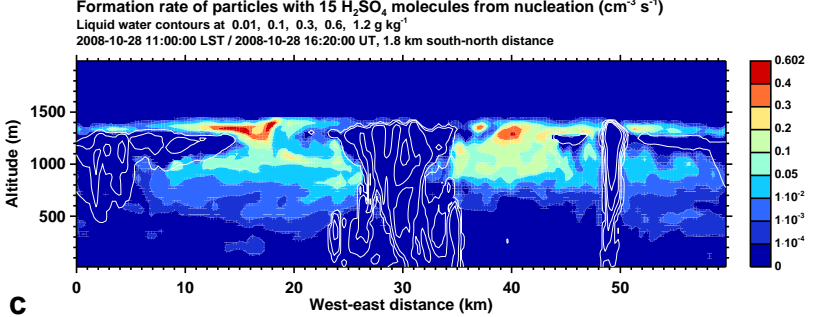

Fig. 5. Vertical slices through the domain of simulation $\mathcal{S}_{0}$ at 28 October 2008 16:20 UT. Contour lines denote liquid water (sum of cloud and rain water). (a) $\mathrm{SO}_{2}$ forms from oxidation of DMS by $\mathrm{OH}$ in the upper boundary layer. Near the ocean surface $\mathrm{SO}_{2}$ occurs in patches with mildly elevated levels, while its mixing ratios are depressed inside the cloudy updrafts due to uptake by liquid water and aqueous chemistry. (b) $\mathrm{H}_{2} \mathrm{SO}_{4}$ forms from oxidation of $\mathrm{SO}_{2}$ by $\mathrm{OH}$ and accumulates in the ultra-clean layer. (c) The elevated $\mathrm{H}_{2} \mathrm{SO}_{4}$ concentrations initiate aerosol nucleation in a thin layer below the inversion and above or between cloud tops.

into the upper MBL exhibits very low aerosol concentrations and aerosol $\mathrm{H}_{2} \mathrm{SO}_{4}$ condensation sink values (Fig. 4a), leading to the formation of an ultra-clean layer, as observed during VOCALS-REx RF06 (Wood et al., 2010). Concurrently, the updrafts loft DMS emitted from the ocean (Fig. 4b). DMS does not readily dissolve in water (De Bruyn et al., 1995), and reaches the MBL top region without being depleted by aqueous chemistry. Here, solar radiation is scattered efficiently by broken clouds, and the enhanced actinic flux results in elevated $\mathrm{OH}$ concentrations (Fig. 4c). The $\mathrm{OH}$ oxidizes DMS to $\mathrm{SO}_{2}$, which accumulates in the cloud-free MBL top region (Fig. 5a). $\mathrm{SO}_{2}$ also occurs in patches with mildly enhanced mixing ratios near the surface, likely due to local conversion of DMS. However, unlike DMS, $\mathrm{SO}_{2}$ dissolves in cloud and rain water and is depleted by aqueous phase chemistry. Its concentrations are therefore depressed inside the cloudy updrafts, and transport from the surface appears to play a secondary role for MBL top concentrations in this case. In the gas phase, $\mathrm{SO}_{2}$ is oxidized by $\mathrm{OH}$ to sulfuric 


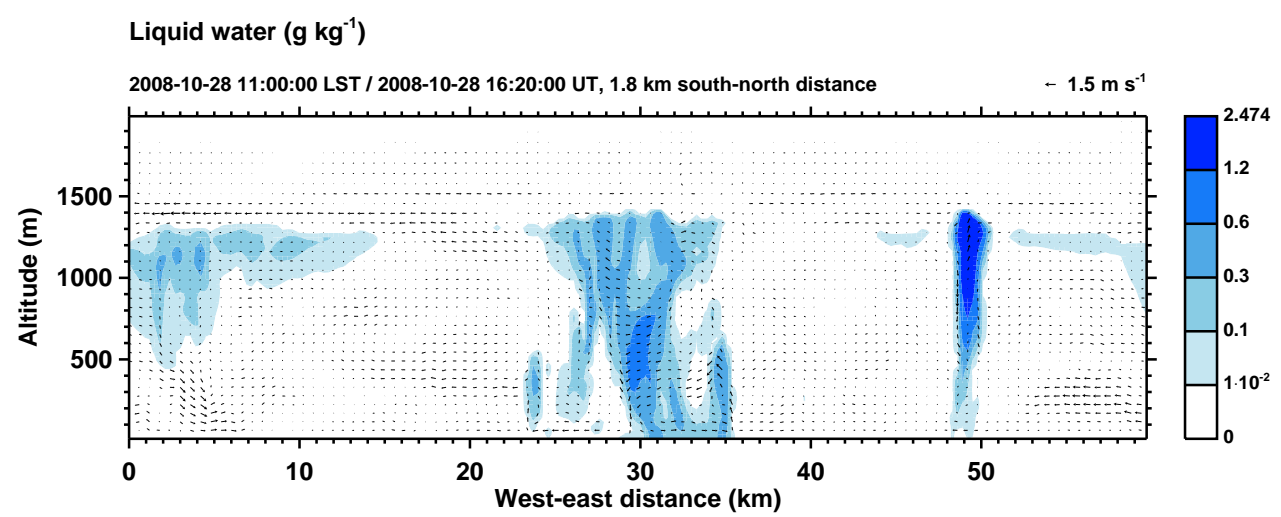

Fig. 6. Liquid water (sum of cloud and rain water), and residual wind velocity in simulation $\mathcal{S}_{0}$ at 28 October 2008 16:20 UT. The maximum updraft velocity is $1.4 \mathrm{~m} \mathrm{~s}^{-1}$, the maximum downdraft velocity $-1.2 \mathrm{~m} \mathrm{~s}^{-1}$.

acid. In the ultra-clean layer, where $\mathrm{H}_{2} \mathrm{SO}_{4}$ aerosol condensation sink values are low (Fig. $4 \mathrm{a}$ ), $\mathrm{H}_{2} \mathrm{SO}_{4}$ accumulates to higher concentrations compared to other levels (Fig. 5b). The elevated $\mathrm{H}_{2} \mathrm{SO}_{4}$ concentrations initiate aerosol nucleation in a thin layer below the inversion and above or between cloud tops (Fig. 5c).

\subsection{Comparison of aerosol sources}

Figure 7 compares the formation rate of particles containing $15 \mathrm{H}_{2} \mathrm{SO}_{4}$ molecules from aerosol nucleation with the source of sea salt particles, averaged over the boundary layer. Aerosol nucleation is negligible during the first $24 \mathrm{~h}$ of the simulation: in the first daytime period, the MBL is in a closed-cell state with an overcast cloud deck and elevated aerosol $\mathrm{H}_{2} \mathrm{SO}_{4}$ condensation sink values (Fig. 3), which remove $\mathrm{H}_{2} \mathrm{SO}_{4}$ from the gas phase, thus suppressing nucleation. Open cells form during the night, but no $\mathrm{H}_{2} \mathrm{SO}_{4}$ that could drive nucleation is available due to the absence of photochemistry. On the next day, however, nucleation sets in in the late morning due to the processes discussed in Sect. 4.1, peaks shortly after local noon, and levels off after a few hours. Sea salt emissions, which are driven by surface winds, proceed continuously throughout the simulation. Integrated over the $24 \mathrm{~h}$ sunrise-to-sunrise period of the second day, and averaged over the boundary layer, formation of particles containing $15 \mathrm{H}_{2} \mathrm{SO}_{4}$ molecules from nucleation amounts to $915 \mathrm{~cm}^{-3}$, and formation of particles in the diameter range $10 \mathrm{~nm}-8 \mu \mathrm{m}$ from sea salt emissions to $45 \mathrm{~cm}^{-3}$. Both values exceed the aerosol replenishment rate of $\sim 1 \mathrm{~cm}^{-3} \mathrm{~h}^{-1}$ that was found sufficient to maintain an open-cell circulation in a Southeast Pacific case study (Wang et al., 2010). However, the relative strength of the two particle formation processes does not quantify their relative effect on $\mathrm{CCN}$ and cloud drop number concentrations: the freshly nucleated particles measure $\sim 1.5-2 \mathrm{~nm}$ in diameter, and need to grow to sizes of tens of nanometers before they can participate as $\mathrm{CCN}$. The larger sea salt aerosol particles on the other hand can be activated to cloud droplets soon after emission.

In order to assess the role of entrainment from the free troposphere as a source of aerosol particles in the boundary layer, we have added an inert gas-phase tracer species to the simulations, which is arbitrarily initialized with $1 \mathrm{ppt}$ above the inversion $\left(1.95 \times 10^{7} \mathrm{~cm}^{-3}\right.$ on average), and with 0 below. The tracer enters the boundary layer due to changes in inversion height and due to mixing at the inversion. At the end of simulation $\mathcal{S}_{0}$ (after $48 \mathrm{~h}$ ), the mean tracer mixing ratio in the boundary layer is $0.13 \mathrm{ppt}\left(3.12 \times 10^{6} \mathrm{~cm}^{-3}\right.$ on average). Therefore, as an estimate, of the $\sim 300 \mathrm{~cm}^{-3}$ particles $>10 \mathrm{~nm}$ in diameter observed in the free troposphere over the POC during VOCALS-REx RF06 (Wood et al., 2010), which is the initial value in our simulations, about $300 \times 3.12 \times 10^{6} / 1.95 \times 10^{7} \mathrm{~cm}^{-3}=48 \mathrm{~cm}^{-3}$ will have entered the boundary layer from above over the course of the $48 \mathrm{~h}$ simulation period. This translates to about $24 \mathrm{~cm}^{-3}$ particles over a $24 \mathrm{~h}$ period, roughly half as many as produced by sea salt emissions in the $>10 \mathrm{~nm}$ size range over the same time period.

\subsection{Uncertainties}

The results of the simulations are subject to various uncertainties, e.g. in the WRF/Chem algorithms that describe the concentrations of gas phase species such as DMS and $\mathrm{SO}_{2}$, aerosol concentrations and liquid water content, and cloud processes. Estimated and observed initial and boundary conditions used in the simulations introduce uncertainties as well. However, the results presented in this work depend perhaps most strongly on the applicability and accuracy of the sea salt emissions and aerosol nucleation scheme, and on the ability of the simulations to describe entrainment from the free troposphere into the MBL. 


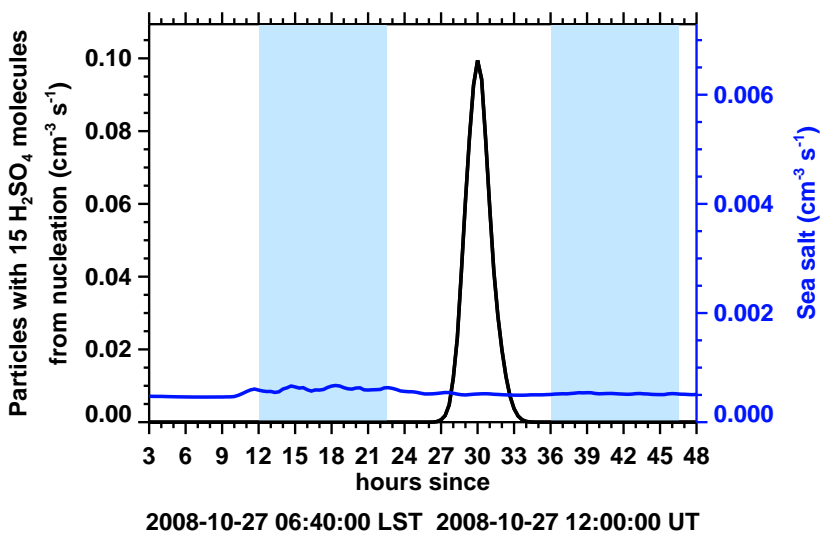

Fig. 7. Formation rate of particles containing $15 \mathrm{H}_{2} \mathrm{SO}_{4}$ molecules from aerosol nucleation (black), and emissions of sea salt particles (blue) from simulation $\mathcal{S}_{0}$, averaged over the boundary layer. Light blue shading indicates nighttime. Nucleation takes place only during the second day of the simulation, after the transition from closed to open cells.

\subsubsection{Gas phase chemistry}

The oxidation of DMS and $\mathrm{SO}_{2}$ in the atmosphere involves a series of reactions (Tyndall and Ravishankara, 1991; Ravishankara et al., 1997) which are represented in the gas phase chemistry scheme with the initial oxidation reaction (Appendix C). This one-stage oxidation scheme can be justified by considering that the rate limiting step is the initial reaction (Tyndall and Ravishankara, 1991; Lovejoy et al., 1996). This approach is commonly used in modeling as well as in the evaluation of field measurements (e.g. Emmons et al., 2010; Faloona et al., 2010), but does not account for effects due to the reactions that follow the initial oxidation reaction.

\subsubsection{Aerosol processes}

Laboratory and field studies indicate that a variety of nucleation mechanisms proceed in the troposphere, and no single mechanism has been found to date which explains all available observations: in addition to sulfuric acid and water (Lovejoy et al., 2004; Hanson and Lovejoy, 2006), elevated concentrations of organic species (Kulmala et al., 2006), iodine (O'Dowd et al., 2002; Burkholder et al., 2004), and ammonia (Coffman and Hegg, 1995; Ball et al., 1999) have been associated with nucleation, and other, poorly understood mechanisms involving amines (Mäkelä et al., 2001; Murphy et al., 2007; Kurtén et al., 2008) or organic nitrates (Fry et al., 2009) may contribute as well. However, in the absence of organic compounds, iodine, ammonia etc. in sufficient amounts, such as in the pristine MBL, sulfuric acid and water appear to be the most likely species involved in nucleation.

The sulfuric acid/water nucleation scheme of Kazil et al. (2010) presumes that the concentrations of ions and small neutral and charged $\mathrm{H}_{2} \mathrm{SO}_{4} / \mathrm{H}_{2} \mathrm{O}$ clusters assume instantaneous steady state values in response to changes in environmental parameters, such as aerosol surface area or gasphase $\mathrm{H}_{2} \mathrm{SO}_{4}$ concentration. This is an imperfect approximation for highly resolved models with short time steps, such as used here: in clouds, the gas phase ion concentration is reduced compared to cloud-free locations due to loss of ions onto cloud water. When an air parcel exits a cloud, the ion concentration will not immediately assume a steady state value, but will build up and approach a steady state value as time progresses. A similar consideration applies to the concentration of small $\mathrm{H}_{2} \mathrm{SO}_{4} / \mathrm{H}_{2} \mathrm{O}$ clusters. Hence the model likely overestimates atmospheric ion concentrations and nucleation rates in air parcels that have recently exited a cloud. The issue is mitigated by the fact that gas phase $\mathrm{H}_{2} \mathrm{SO}_{4}$, which is required for the formation of small $\mathrm{H}_{2} \mathrm{SO}_{4} / \mathrm{H}_{2} \mathrm{O}$ clusters and for nucleation, is approximately zero inside clouds, and will build up to concentrations that support significant nucleation rates only over time in air parcels that have left the cloud. Therefore, the overestimation of the ion concentration in these air parcels occurs when nucleation is limited due to low gas phase concentrations of sulfuric acid.

While the aerosol nucleation scheme used in this work accounts for the Kelvin effect in the calculation of condensational growth of aerosol particles, it is neglected in the MADE aerosol scheme (Ackermann et al., 1998). Therefore, growth of freshly nucleated particles due to condensation of sulfuric acid from the gas phase will be likely overestimated in the model, in spite of the extremely small vapor pressure of sulfuric acid.

In the current implementation, WRF/Chem calculates the partitioning of sulfate, ammonium, nitrate, and water between aerosol and the gas phase without taking into account the $\mathrm{Na}^{+}$and $\mathrm{Cl}^{-}$content of the particles. The consequence will be an underestimation of the aerosol liquid water content, surface area, and $\mathrm{H}_{2} \mathrm{SO}_{4}$ condensation sink. This will lead to an underestimation of the removal of gas phase $\mathrm{H}_{2} \mathrm{SO}_{4}$ and of ultrafine particles, and to an overestimation of aerosol nucleation rates. No adverse effects are expected on aerosol activation, which is determined from dry particle sizes.

\subsubsection{Sea salt emissions and entrainment from the free troposphere}

The relative strength of the oceanic and free tropospheric contribution to MBL aerosol, discussed in Sect. 4.2, is likely not representative for these sources in general, and is subject to model deficiencies. Firstly, the concentration of free tropospheric aerosol used in our simulations represents a mean value during VOCALS-REx RF06 (Wood et al., 2010), but in the course of the flight, this concentration shows substantial variability. Secondly, entrainment from the free troposphere into the MBL may be patchy in character, depending on 
turbulence, and result in fortuitous entrainment from regions with high or low free tropospheric aerosol concentrations. Furthermore, the resolution of the simulations determines how well small scale mixing at the inversion and variations of the inversion height, which are responsible for entrainment, are represented. Stevens et al. (2005b) found that even at a comparably fine vertical resolution of $5 \mathrm{~m}$, large eddy simulations greatly overestimate mixing and entrainment at cloud top. Given the coarse vertical resolution used in our simulations, entrainment is undoubtedly overestimated.

The sea salt emissions scheme used in this work (Clarke et al., 2006) may not be equally applicable to all oceanic regions, e.g. because of effects of organic matter in sea water, which are not accounted for in the scheme. The contribution of organic matter to primary oceanic aerosol was investigated by Leck and Bigg (2005) and Russell et al. (2010), but uncertainty exists in the amount of organic mass in these particles (Bigg and Leck, 2008; Modini et al., 2010). Fuentes et al. (2010) found an increase in the production of sea spray particles with dry diameter $<100 \mathrm{~nm}$ with increasing amounts of organic matter in sea water, but concluded that this effect is only expected to be significant in areas of high biological activity. Given the low sea water chlorophyll concentrations in the VOCALS-REx region seen in MODIS satellite-derived imagery, we expect that this has no bearing on the results. A separate study (Shank et al., 2011) has found a negligible oceanic source of organic aerosol during VOCALS-REx. In addition, in the clean MBL, aerosol composition has little bearing on cloud droplet activation (Feingold, 2003; Ervens et al., 2005); it is therefore reasonable to apply the Clarke et al. (2006) parameterization as a proxy for all oceanemitted particles.

\section{Comparison with VOCALS-REx}

\subsection{Measurements}

VOCALS-REx measurements conducted on board the NCAR C-130 aircraft during RF06 (Wood et al., 2010) and on board the NOAA research vessel Ronald H. Brown are used for evaluation of the simulations. RF06 took place in the late night/early morning hours of 28 October 2008, between 08:00 and 13:30 UT, with extended horizontal legs and shorter ascents/descents across a POC (Fig. 8). The simulations are compared against vertical profiles taken at 09:05 UT and 11:36 UT. These profiles originate from different parts of the POC: the earlier profile (09:05 UT) was taken near the center of the POC, an area with comparably low infrared emissions (Fig. 8a). The later profile (11:36 UT) on the other hand stems from an area with high visible reflection and farther away from the center of the POC (Fig. 8b). The denser cloud at the location of the later profile indicates that it represents an area where the transition from closed to open cells

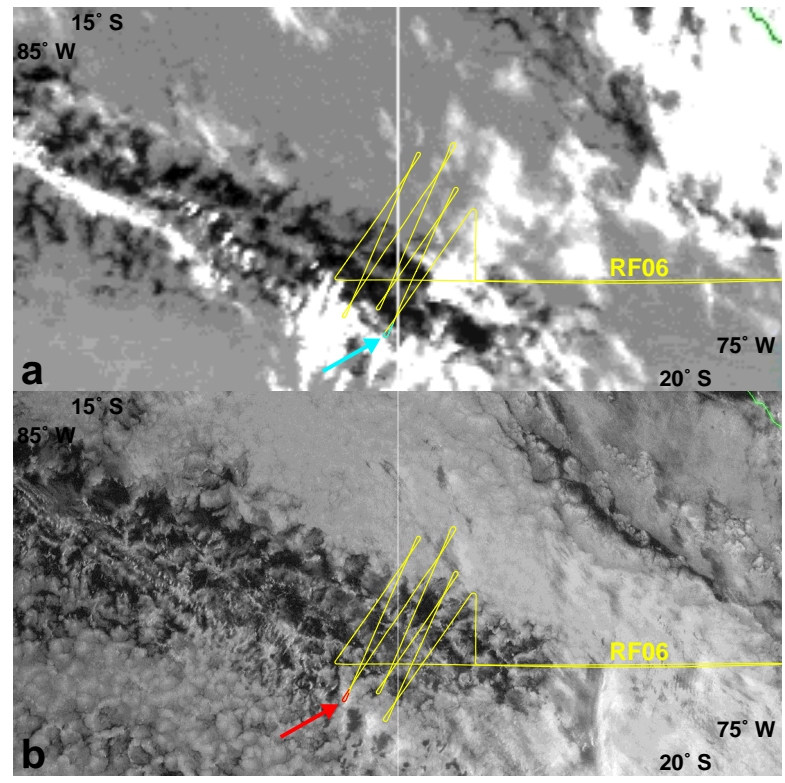

Fig. 8. GOES-10 imagery on 28 October 2008 in thermal infrared at 08:45 UT (a) with $4 \mathrm{~km}$ resolution, and in visible at 11:45 UT (b) with $1 \mathrm{~km}$ resolution, and the VOCALS-REx RF06 flight route (yellow). Locations of POC profiles taken at 09:05 UT and 11:36 UT are marked in cyan and red, respectively. The satellite images cover the Southeast Pacific from $75-85^{\circ} \mathrm{W}$, and from $15-20^{\circ} \mathrm{S}$.

has not progressed as far as at the location of the earlier profile, as will be discussed in Sect. 5.2.

Several instruments on board the NCAR C-130 aircraft determined cloud and rain water: the Particle Measuring Systems (PMS) Two Dimensional Cloud Probe (2D-C) measured the mass of hydrometeors in the $25-800 \mu \mathrm{m}$ diameter range. The mass of smaller liquid particles was determined with the PMS King probe (King et al., 1978), which samples efficiently in the diameter range 5-40 $\mu \mathrm{m}$. Both instruments report a liquid water content with a low bias dictated by their preferred detection range. In drizzling conditions, the 2D-C probe includes a more significant fraction of the total liquid water than does the King probe and so $2 \mathrm{D}-\mathrm{C}$ data are used in the following.

Atmospheric DMS and $\mathrm{SO}_{2}$ concentrations were measured on board the NCAR C-130 by isotope dilution atmospheric pressure ionization mass spectrometry (Bandy et al., 2002; Thornton et al., 2002). $\mathrm{SO}_{2}$ was sampled at $25 \mathrm{~Hz}$, with a lower limit of detection of $\sim 1 \mathrm{ppt}$ at an integration time of $1 \mathrm{~s}$. DMS was sampled at $0.1 \mathrm{~Hz}$, with a lower limit of detection of $\sim 1 \mathrm{ppt}$ at this frequency. Identical instruments (with different sampling frequencies) were used on board the NOAA Ronald H. Brown to determine atmospheric DMS and $\mathrm{SO}_{2}$ concentrations near the ocean surface, as well as the oceanic DMS flux (Yang et al., 2009).

Concentrations of atmospheric aerosol particles with (dry) diameters in the range $120 \mathrm{~nm}-3.12 \mu \mathrm{m}$ were measured with the wing-mounted PMS Passive Cavity Aerosol 
Spectrometer Probe (PCASP). Aerosol particles down to a cutoff (dry) diameter of $3 \mathrm{~nm}$ and $10 \mathrm{~nm}$ (where the detection efficiency falls to $50 \%$ ) were measured using cabinbased TSI 3025 and TSI 3010 Condensation Particle Counters (CPC), respectively. The CPCs sample from a manifold serviced by a forward-facing inlet, and may pick up particles that form due to shattering of hydrometeors on the front of the inlet. CPC data taken inside clouds and in the presence of rain are therefore discarded. The PCASP instrument is subject to similar artifacts from shattering hydrometeors, and its data are discarded at the corresponding locations as well. Analyses of aerosol plumes documented by both the CPCs and the PCASP revealed a $3 \mathrm{~s}$ (TSI 3025) and a $5 \mathrm{~s}$ (TSI 3010) lag between the PCASP and the cabin-based CPCs, which is corrected for in the data analysis.

The concentration of aerosol particles in the diameter interval 3-10 nm (ultrafine nuclei) was obtained by differencing the particle concentrations from the two CPCs subsequent to correction for the lag and exclusion of data from cloud and precipitation intervals. An enhancement in the ultrafine nuclei concentration indicates nucleation from the gas phase. A criterion for unambiguous detection of ultrafine particles is a significantly higher concentration measured by the TSI 3025 compared to the TSI 3010 . We require that the relative difference of the CPC concentrations exceeds $20 \%$ for at least $10 \mathrm{~s}$. Based on this criterion, no ultrafine nuclei were detected in the MBL during the profiles taken at 09:05 UT and 11:36 UT. This indicates absence of nucleation in the MBL during and prior to RF06. Unambiguous detection of ultrafine particles took place above the MBL in layers at altitudes near $5.5 \mathrm{~km}, 3.5 \mathrm{~km}$, and in a pollution layer above $1.6 \mathrm{~km}$.

It is plausible that a low-level overcast cloud deck occurring on the day before RF06 (Wood et al., 2010) prevented photochemically driven aerosol nucleation within the boundary layer by limiting the actinic flux that drives the conversion of $\mathrm{SO}_{2}$ to $\mathrm{H}_{2} \mathrm{SO}_{4}$ and by scavenging gas phase sulfuric acid. Nonetheless, analysis of aerosol size distributions taken with a Differential Mobility Particle Sizer (DMPS) during RF06 shows the presence of a mode of small particles with $\sim 20 \mathrm{~nm}$ in diameter in the MBL and free troposphere (at $160 \mathrm{~m}$ and $1600 \mathrm{~m}$, respectively). This indicates that entrainment from the free troposphere can be a source of very small MBL aerosol. This aerosol mode was also frequently observed in other clean VOCALS MBL regions where nucleation was not directly evident. Heating of these particles to $300^{\circ} \mathrm{C}$ revealed that they consisted of volatile compounds at this temperature. Similar volatility measurements over the remote Pacific in the MBL (Clarke et al., 1998) and free troposphere (Clarke et al., 1999; Clarke and Kapustin, 2002), all made in conjunction with gas phase sulfuric acid, implicate the latter as the primary component in these nuclei. More diverse and detailed observations of nucleation and entrainment during VOCALS and their relationship to $\mathrm{CCN}$ will be the subject of a separate paper.

\subsection{Cloud condensation nuclei and liquid water}

A layer with extremely low concentrations $\left(\gtrsim 0.1 \mathrm{~cm}^{-3}\right)$ of particles $>120 \mathrm{~nm}$ in diameter was found during VOCALSREx RF06 at cloud level in the sampled POC, approximately $200 \mathrm{~m}$ below the inversion base (Wood et al., 2010). In the sub-cloud layer, concentrations of aerosol particles in this size range were considerably higher at $20-60 \mathrm{~cm}^{-3}$. This contrast suggests that very efficient scavenging of $\mathrm{CCN}$ by collision-coalescence and precipitation has taken place in updrafts of the open-cell circulation, with subsequent detrainment of the purged air below the inversion, which created the ultra-clean layer.

Figure 9 compares concentrations of aerosol particles $>120 \mathrm{~nm}$ in diameter and liquid water (sum of cloud and rain water) from simulation $\mathcal{S}_{0}$ with POC profiles obtained during RF06 at 09:05 UT and 11:36 UT. The observed profiles were taken in different parts of the POC, as discussed in Sect. 5.1, and do not represent a continuous temporal evolution of the MBL from the closed- to the open-cell state. The 09:05 UT profile originates from an airmass with low infrared emissions near the center of the sampled POC (Fig. 8a), indicative of more mature open cells with low cloud fraction, while the 11:36 UT profile stems from an area with a high visible reflection farther from the core of the POC (Fig. 8b) with higher cloud fraction.

At 09:00 UT, simulation $\mathcal{S}_{0}$ features an ultra-clean layer with minimum aerosol concentrations at about $200 \mathrm{~m}$ below mean cloud top height, in excellent agreement with the $>120 \mathrm{~nm}$ aerosol profile observed a 09:05 UT (Fig. 9a). Simulated liquid water exhibits a peak near mean cloud top height and a drizzle tail extending to the surface (Fig. 9b) from the contribution of optically thick, precipitating clouds located along open cell peripheries (Fig. 2b). The NCAR C-130 aircraft was crossing a nearly cloud-free area at 09:05 UT, and liquid water was detected only in a narrow altitude band around $500 \mathrm{~m}$, possibly remnants of a decaying cell wall.

By 11:40 UT, the ultra-clean layer has deepened in the simulation, and below-cloud $>120 \mathrm{~nm}$ aerosol concentrations have been further reduced (Fig. 9c). The simulated liquid water profile shows a more pronounced drizzle tail (Fig. 9d). These changes are consistent with a progression from less to more mature open cells between 09:00 UT (Fig. 9a and b) and 11:40 UT (Fig. 9c and d) in the simulation, with intensifying precipitation and stronger aerosol wet deposition. The aerosol profile observed at 11:36 UT (Fig. 9c), however, shows comparably high below-cloud concentrations, higher than those observed earlier at 09:05 UT (Fig. 9a). At the same time, the observed liquid water profile does not exhibit a drizzle tail (Fig. 9d). This supports the contention that the later measurements represent an earlier stage of the closed-to-open cell transition. Indeed, the simulation is in much better agreement at 03:20 UT with the later observations (Fig. 9c and d), when cloud fraction is still near 

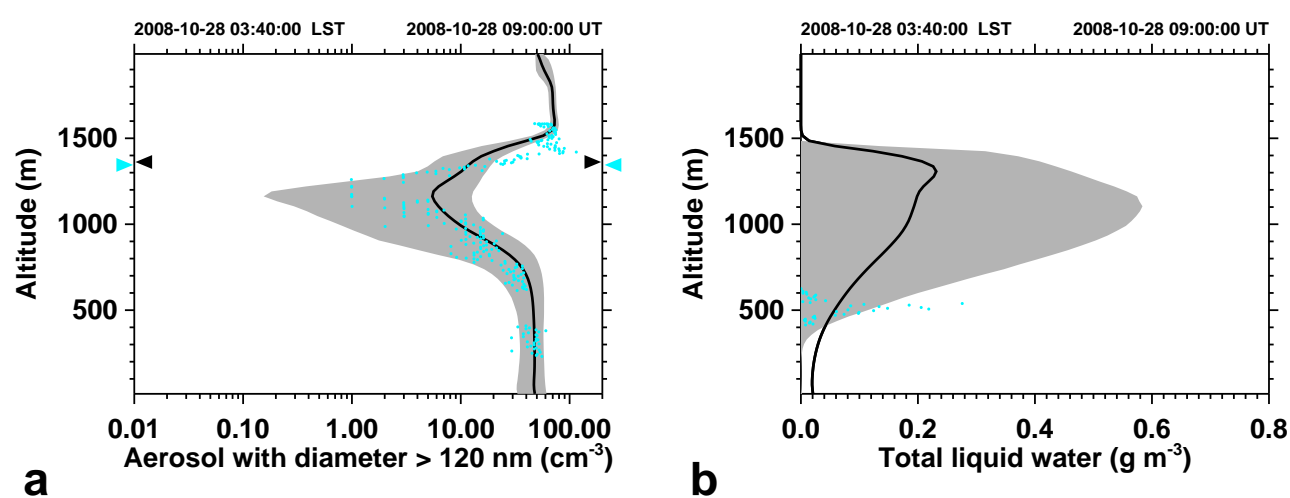

a
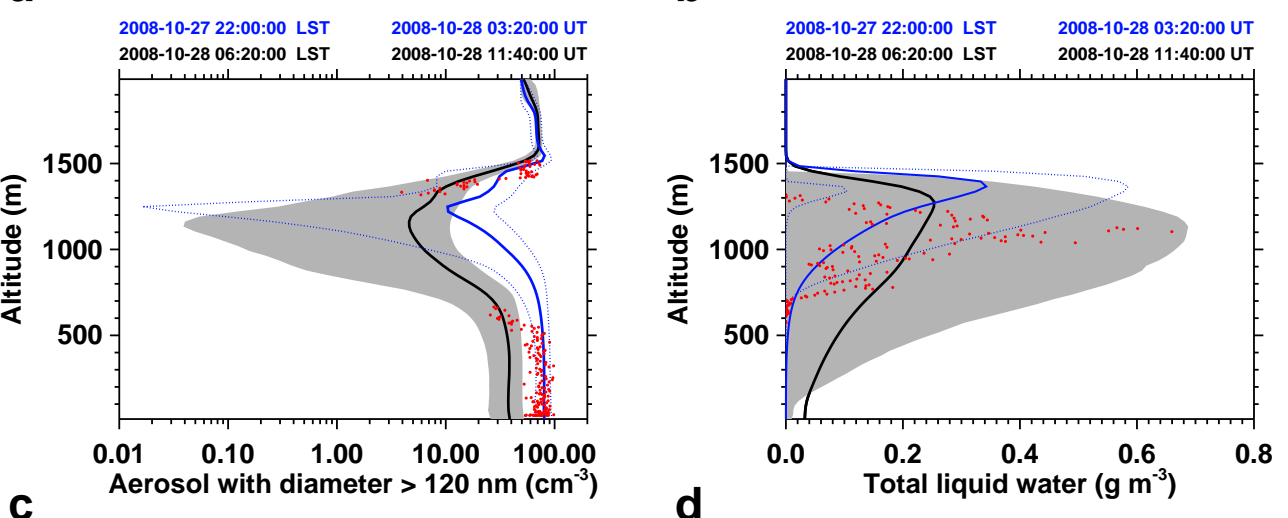

Fig. 9. Comparison of results from simulation $\mathcal{S}_{0}$ (black and blue) with VOCALS-REx RF06 POC observations at 09:05 UT (cyan dots) and at 11:36 UT (red dots). Solid curves denote the model mean, gray shading and dotted blue curves model values between the 10th and 90th percentile. Cyan and black triangles mark the observed and simulated mean cloud top height, respectively. Panel (a) and (c) show average concentrations of aerosol particles $>120 \mathrm{~nm}$ dry diameter at cloud-free locations. The observed aerosol concentrations, measured by the PCASP instrument on board the NCAR C-130 aircraft, are plotted only at locations with a liquid water content $<0.03 \mathrm{~g} \mathrm{~m}^{-3}$ and a rain drop number $<0.001 \mathrm{~cm}^{-3}$ in order to exclude artifacts from shattering of cloud and rain droplets. The model results represent aerosol concentrations at locations with a cloud water content $<0.01 \mathrm{~g} \mathrm{~kg}^{-1}$. Panel (b) and (d) show liquid water (sum of cloud and rain water) mixing ratios averaged over cloudy and cloud-free locations; the observed values were measured by the 2D-C probe on board the NCAR C-130 aircraft.

unity and before the onset of precipitation (see Fig. 3a and b), hence at an early stage of the closed-to-open cell transition. The lack of a drizzle tail in the observed liquid water profile at 11:36 UT, as well as the disagreement in the simulated and observed liquid water peak height (Fig. 9d) may be, however, due to an undersampling bias.

\subsection{DMS}

Figure 10 compares DMS from simulations $\mathcal{S}_{0}$ and $\mathcal{S}_{1}$ at 09:00 UT and 11:40 UT with concurrent surface measurements on board the NOAA research vessel Ronald H. Brown, and with the available aircraft DMS POC profile at 11:36 UT. The two simulations differ in the DMS flux from the ocean: $\mathcal{S}_{0}$ uses the mean VOCALS-REx flux at $80^{\circ} \mathrm{W}, 20^{\circ} \mathrm{S}$ of $4.8 \mu \mathrm{mol} \mathrm{m}{ }^{-2} \mathrm{~d}^{-1}$, derived from the shipboard DMS data. In simulation $\mathcal{S}_{1}$, the DMS flux is reduced by a factor of 0.5 . The shipboard measurements of DMS and of the oceanic DMS flux during VOCALS-REx are discussed by Yang et al. (2009).
The simulated DMS profiles are shaped by surface emissions from the ocean and convective lifting into the upper MBL, with high values near the surface, low values in the mid-MBL, and elevated values below the inversion height. $\mathcal{S}_{0}$ is in excellent agreement with the shipboard DMS data at 09:00 UT, while $\mathcal{S}_{1}$ underestimates them by approximately a factor of 0.5 (Fig. 10a). At 11:40 UT, $\mathcal{S}_{0}$ reproduces the shipboard DMS measurements well, while $\mathcal{S}_{1}$ is in very good agreement with the aircraft data (Fig. 10b).

How does one reconcile the differences in Fig. 10b? The surface DMS measurements were taken over the course of one hour centered around 11:40 UT on 28 October 2008 on board the NOAA Ronald H. Brown, at $82.4^{\circ} \mathrm{W} 19.65^{\circ} \mathrm{S}$. The aircraft DMS profile was acquired on board the NCAR C130 over a $5 \mathrm{~min}$ period (a flight path of $\sim 30 \mathrm{~km}$ ) around $11: 36 \mathrm{UT}$ on 28 October 2008 at $80.7^{\circ} \mathrm{W}, 19^{\circ} \mathrm{S}$, hence at a distance of about $200 \mathrm{~km}$ east-northeast. Yang et al. (2009) found that in the diurnal mean, the gradient in surface DMS during VOCALS-REx was perpendicular to the mean wind 


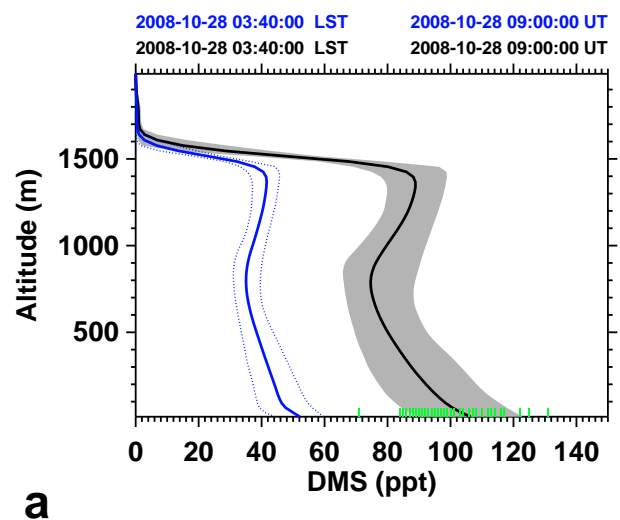

a

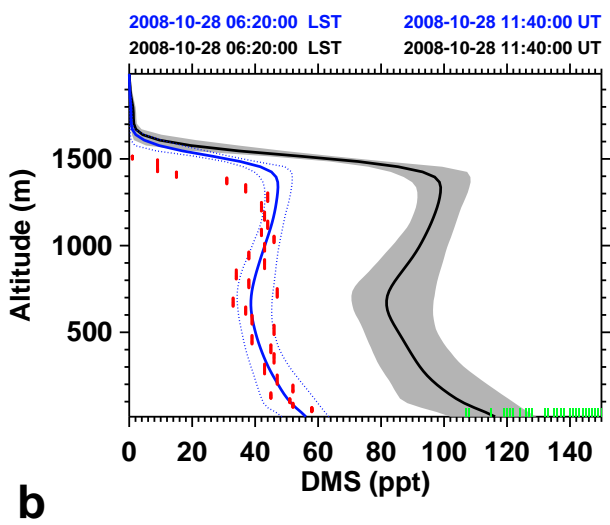

Fig. 10. Comparison of DMS from simulation $\mathcal{S}_{0}$ (black) and $\mathcal{S}_{1}$ (blue) at (a) 09:00 UT and (b) 11:40 UT with VOCALS-REx RF06 POC observations at 11:36 UT (red dots) on board the NCAR C-130 aircraft, and surface measurements during a $1 \mathrm{~h}$ period centered around the indicated times on board the NOAA research vessel Ronald H. Brown (green bars). Solid curves denote the model mean, gray shading and dotted blue curves model values between the 10th and 90th percentile.

direction, south-southeast. The ship and aircraft locations at the time of the measurements are aligned with this mean horizontal DMS gradient, which Yang et al. determined as $-2 \mathrm{ppt}^{\circ} \mathrm{Lon}^{-1}$ and $-1 \mathrm{ppt}^{\circ} \mathrm{Lat}^{-1}$. The mean horizontal gradient would therefore account for a difference of at most a few ppt between the shipboard and the aircraft DMS data. A variation in DMS that would explain the observed difference between the ship and aircraft data would hence need to play out on timescales shorter than a day, on a spatial scale of $\sim 200 \mathrm{~km}$, and amount to a factor of at least two. However, no such variation is seen in the shipboard DMS time series (Yang et al., 2009); the largest variation is the diurnal cycle with a factor of about two. We therefore conclude that the observed spatial variability in surface DMS is unlikely to explain the difference between the shipboard data and the aircraft measurements.

It is worthwhile considering that the observed DMS flux of $4.8 \mu \mathrm{mol} \mathrm{m}^{-2} \mathrm{~d}^{-1}$ would bring about an increase of DMS by $39 \mathrm{ppt}$ in the MBL over the duration of the night (10 h $40 \mathrm{~min}$ ). A mean inversion base height of $1375 \mathrm{~m}$ during RF06 (Wood et al., 2010), a mean MBL temperature of $287.5 \mathrm{~K}$, and a mean MBL pressure of $945 \mathrm{hPa}$ based on our simulations were assumed here. Accounting for a mean loss of DMS by $-0.6 \mu \mathrm{mol} \mathrm{m}^{-2} \mathrm{~d}^{-1}$ from the MBL due to entrainment, determined by Yang et al., the total nighttime increase would amount to $37 \mathrm{ppt}$. However, the mean aircraft DMS mixing ratio is $\sim 42 \mathrm{ppt}$ in the early morning MBL (Fig. 10b), hence with the observed flux, and provided no nighttime chemical loss has occurred, DMS levels would have to be around $5 \mathrm{ppt}$ at sunset. This is an implausible proposition, as revealed by the shipboard measurements of DMS that show typical evening values of $60 \mathrm{ppt}$, and no values below 20 ppt (Yang et al., 2009). Hence, in the absence of nighttime chemical loss, the aircraft DMS profile in Fig. 10b suggests a lower oceanic DMS flux than the shipboard measurements.
An alternative explanation of the low aircraft DMS values in the MBL (Fig. 10b) is oxidation by $\mathrm{NO}_{3}$, the only known nighttime chemical loss process of DMS. Based on test simulations with the observed DMS flux of $4.8 \mu \mathrm{mol} \mathrm{m}^{-2} \mathrm{~d}^{-1}$, we find that $\mathrm{NO}_{\mathrm{x}}$ around $90 \mathrm{ppt}$ would be required to reproduce the aircraft DMS profile. However, $\mathrm{CO}(\sim 64 \mathrm{ppb})$ and $\mathrm{SO}_{2}$ $(\lesssim 50 \mathrm{ppt})$ values observed in the MBL during RF06 indicate that the study area was unaffected by long-range transport of pollution, and hence would exhibit $\mathrm{NO}_{\mathrm{x}}$ at typical levels for the clean marine environment. No measurements of $\mathrm{NO}_{\mathrm{x}}$ were conducted during VOCALS-REx, but Olson et al. (2001) found $5-10 \mathrm{ppt} \mathrm{NO}_{\mathrm{x}}$ in the Pacific between $10^{\circ} \mathrm{S}-$ $30^{\circ} \mathrm{S}$ during PEM-Tropics A and $\mathrm{B}$ in the lowest $2 \mathrm{~km}$ of the atmosphere, and Sommariva et al. (2004) report $\mathrm{NO}_{2}$ levels not exceeding $15 \mathrm{ppt}$ in pristine air of the South Pacific at Cape Grim. Concurrently, Yang et al. (2009) have found that oxidation by $\mathrm{NO}_{3}$ was an insignificant loss process of DMS during VOCALS-REx. We therefore conclude that the low DMS values seen in the aircraft profile (Fig. 10b) are unlikely due to nighttime oxidation by $\mathrm{NO}_{3}$.

To summarize, the model reproduces the VOCALS-REx shipboard DMS measurements when the observed oceanic DMS flux is used, and the VOCALS-REx RF06 DMS measurements when the observed oceanic DMS flux is reduced by a factor of 0.5 . The good agreement between the observed and simulated shape of the vertical profile indicates a correct treatment of transport and chemical loss of DMS in the model. The aircraft DMS profile and the shipboard measurements of DMS mixing ratio and oceanic flux cannot be easily reconciled: spatial and temporal variability in surface DMS levels and oceanic DMS flux is insufficient to explain the aircraft DMS measurements. Nighttime oxidation of DMS by $\mathrm{NO}_{3}$ could harmonize the observed oceanic DMS flux and the aircraft DMS profile, but would require $\mathrm{NO}_{\mathrm{x}}$ levels significantly above those typically found in the unpolluted marine boundary layer. 

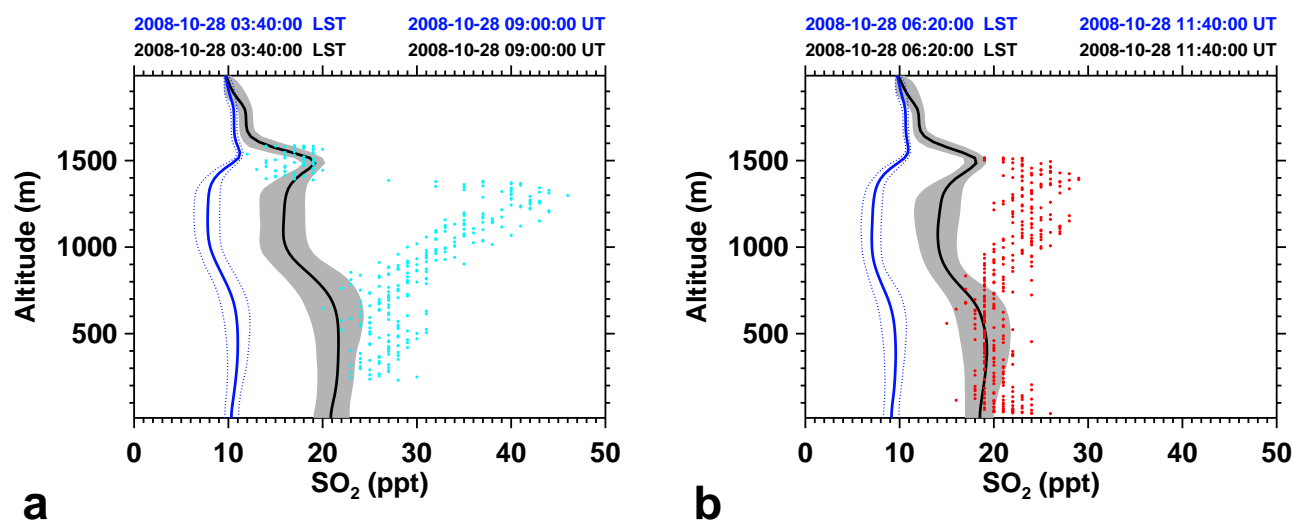

Fig. 11. Comparison of $\mathrm{SO}_{2}$ from simulation $\mathcal{S}_{0}$ (black) and $\mathcal{S}_{1}$ (blue) at (a) 09:00 UT and (b) 11:40 UT with VOCALS-REx RF06 POC observations at 09:05 UT (cyan dots) and at 11:36 UT (red dots) on board the NCAR C-130 aircraft. Solid curves denote the model mean, gray shading and dotted blue curves model values between the 10th and 90th percentile.

\section{$5.4 \mathrm{SO}_{2}$}

Figure 11 compares $\mathrm{SO}_{2}$ from simulation $\mathcal{S}_{0}$ and $\mathcal{S}_{1}$ at 09:00 UT and 11:40 UT with VOCALS-REx RF06 POC profiles at 09:05 UT and 11:36 UT. Surface $\mathrm{SO}_{2}$ measurements were conducted on board the NOAA Ronald H. Brown, but are not available at the time of writing. The simulated $\mathrm{SO}_{2}$ profiles are shaped by chemical production (oxidation of DMS by $\mathrm{OH}$ ) and loss (oxidation of $\mathrm{SO}_{2}$ by $\mathrm{OH}$ ) during daytime, loss due to aqueous chemistry in cloud and rain water, and turbulent mixing in the MBL. $\mathrm{SO}_{2}$ mixing ratios in simulation $\mathcal{S}_{0}$ are comparable to observed values in the belowcloud layer, but clearly too low at cloud level, where the measurements show an $\mathrm{SO}_{2}$ peak. Simulation $\mathcal{S}_{1}$ produces systematically low $\mathrm{SO}_{2}$ compared to the observations owing to a reduced oceanic DMS flux.

The observed $\mathrm{SO}_{2}$ peaks at cloud level are counterintuitive, in particular in the case of the 11:36 UT (Fig. 11b) profile, where the peak is located inside a cloud layer (see Fig. 9d). Inside clouds, an efficient $\mathrm{SO}_{2}$ removal by aqueous chemistry is common, except in $\mathrm{H}_{2} \mathrm{O}_{2}$ limited conditions. The simulations are not $\mathrm{H}_{2} \mathrm{O}_{2}$ limited, with $\sim 900 \mathrm{ppt}$ of this compound at cloud level exceeding $\mathrm{SO}_{2}$ by more than an order of magnitude. The simulated $\mathrm{H}_{2} \mathrm{O}_{2}$ is consistent with observations in the Southeast Pacific (O'Sullivan et al., 2004).

In a pollution-influenced marine environment, $\mathrm{NO}_{\mathrm{x}}$ levels can lead to nighttime oxidation of DMS by $\mathrm{NO}_{3}$ at rates that are comparable to those of daytime oxidation by $\mathrm{OH}$ (Yvon et al., 1996). The associated formation of $\mathrm{SO}_{2}$ could therefore produce elevated $\mathrm{SO}_{2}$ concentrations at night and in the early morning compared to unpolluted conditions. However, as discussed in Sect. 5.3 and by Yang et al. (2009), no indications of DMS oxidation by $\mathrm{NO}_{3}$ during VOCALS-REx at rates above those typical for the clean marine boundary layer exist. We therefore conclude that the observed night- time/early morning peaks in $\mathrm{SO}_{2}$ at cloud level are unlikely due to nighttime oxidation of DMS by $\mathrm{NO}_{3}$.

\section{Conclusions}

Marine stratiform clouds organize into two boundary layer dynamic states that exhibit closed- or open-cell convective circulation: closed-cell circulation features a high cloud fraction and relatively low drizzle rates, while open-cell circulation displays vigorous updrafts, and optically thick, strongly precipitating clouds in the open cell walls, and optically thin clouds in the cell interiors. Wet scavenging in open cell walls efficiently removes aerosol particles, which, unless compensated, would ultimately lead to a halt of cloud formation and cloud top cooling, and to a cessation of boundary layer circulation. Hence, for the open-cell circulation to be maintained, aerosol sources such as emissions of sea salt particles from the ocean, nucleation from the gas phase, and entrainment from the free troposphere are needed to replenish the aerosol population. In order to investigate the processes supplying aerosol particles in the marine boundary layer, we have coupled in detail chemical, aerosol, and cloud processes in the WRF/Chem model and added state-of-the-art representations of sea salt emissions and of aerosol nucleation from the gas phase.

Simulations of a cloudy boundary layer in transition from closed to open cells were conducted for a region in the Southeast Pacific sampled during VOCALS-REx, and the results compared with observations. The model reproduces observed concentrations of cloud condensation nuclei and of DMS in open cells during VOCALS-REx Research Flight 6 (RF06), although the observed DMS aircraft and shipboard data exhibit a discrepancy. The model does not reproduce observed $\mathrm{SO}_{2}$ peaks at cloud level and inside clouds.

The simulations show that the transition from closed to open cells generates conditions that are conducive to 
nucleation from the gas phase, which produces new aerosol particles in the MBL: cloud-processed air from open cell updrafts forms an ultra-clean layer beneath the inversion height with extremely low aerosol concentrations. Concurrently, open cell updrafts transport DMS from the ocean surface into this layer, where it is oxidized in the presence of elevated $\mathrm{OH}$ concentrations to $\mathrm{SO}_{2}$ and ultimately to $\mathrm{H}_{2} \mathrm{SO}_{4}$. Due to the very low concentrations of pre-existing aerosol in the ultra-clean layer, $\mathrm{H}_{2} \mathrm{SO}_{4}$ is removed only slowly from the gas phase and accumulates to concentrations at which aerosol nucleation produces new particles in significant numbers. Since the nucleation process is driven by the photochemically produced $\mathrm{OH}$ radical, it peaks shortly after midday, with highest nucleation rates in the vicinity of cloud tops, where scattering from cloud and rain droplets enhances the actinic flux and $\mathrm{OH}$ formation.

We find that the observed DMS flux from the ocean in the VOCALS-REx region can support a nucleation source of aerosol in open cells that exceeds sea salt emissions in terms of the number of particles produced. This result is consistent with one of the underpinnings of the CLAW hypothesis, which proposes that in broken cloud situations ocean phytoplankton respond to the increased surface radiation and temperature by producing more DMS, which in turn, results in stronger aerosol nucleation in the MBL, an increased number of aerosol particles, and a higher cloud albedo/fraction. However, the freshly nucleated aerosol particles are much smaller than sea salt aerosol emitted from the ocean surface, and need to grow to larger sizes before they can affect the $\mathrm{CCN}$ and cloud drop number. Sea salt emissions on the other hand exceed an aerosol replenishment rate in our simulations that has been found sufficient to maintain an open-cell circulation in the cloudy Southeast Pacific boundary layer. Finally, we find that entrainment of aerosol from the free troposphere contributes significantly to boundary layer aerosol for the considered VOCALS-REx case, but less than sea salt aerosol emissions.

The results presented here form the groundwork for future research on the behavior of aerosol sources and their determining factors in the marine boundary layer, and on their role for cloud properties.

\section{Appendix A}

\section{Coupling of chemical, aerosol, and cloud processes}

\section{A1 Aerosol and cloud microphysics}

The aerosol quantities provided by the WRF/Chem MADE module to the cloud microphysics scheme are particle number concentration $\left(\mathrm{kg}^{-1}\right)$ and mass mixing ratio $\left(\mu \mathrm{g} \mathrm{kg}^{-1}\right)$ of interstitial aerosol and aerosol residing in liquid water. Both are resolved by aerosol mode, and the latter is also resolved by chemical composition. The WRF/Chem MADE module does not distinguish aerosol in cloud and rain water. On the other hand, the cloud microphysics scheme tracks interstitial aerosol, aerosol in cloud water, and aerosol in rain water, but does not resolve aerosol number by aerosol mode. The coupling must therefore take into consideration, and preserve the basic information for each scheme.

We are aided by two main factors: (i) the fact that the droplet concentration (cloud plus rain) represents the potential number concentration of aerosol particles that can be regenerated to the atmosphere at any time. Thus aerosol particle concentration inside of droplets is assumed at any time to be equal to the cloud plus rain drop concentration, and partitioned based on the ratio of cloud to rain drop number concentrations; and (ii) that the aerosol can be considered to be a passive tracer within the droplets, which facilitates mass transfer between cloud and rain.

The cloud microphysics scheme calculates the number of newly activated particles from each of the three MADE aerosol modes from the dry geometric mean diameter and the number of interstitial particles, and based on the calculated ambient water vapor supersaturation (Feingold et al., 1998). The total number of newly activated particles is added to the number of particles residing in cloud droplets, and the cloud drop number concentration is updated accordingly. The mass of the newly activated particles is added to the mass of particles residing in cloud droplets, resolved by aerosol mode and chemical composition.

As water condenses onto cloud droplets and converts a given number (mass) fraction thereof into rain droplets, the cloud microphysics scheme transfers the same fraction of aerosol number (mass) from the cloud drop to the rain drop population. Aerosol mass transfer between cloud water and rain is resolved by the aerosol mode from which it was derived and the chemical composition. Transfer of aerosol number and mass in the opposite direction takes place as water evaporates from rain droplets, converting them into cloud droplets. Evaporation of water from cloud droplets that reduces cloud water below a given threshold $\left(10^{-7} \mathrm{~kg} \mathrm{~kg}^{-1}\right)$ results in a transfer of all aerosol number and aerosol mass from cloud droplets to interstitial aerosol.

Collision-coalescence transfers aerosol mass from cloud droplets to rain droplets at the same relative rate as the water mass transfer. This results in the aerosol mass scaling with the water mass as in Flossmann et al. (1985). By reducing drop number concentration, collision-coalescence also reduces the number concentration of aerosol particles that can be potentially returned to the atmosphere upon complete evaporation. This is equivalent to the assumption that the particles in coalescing cloud/rain droplets merge. This treatment accounts for the effect of collision-coalescence on aerosol number and mass within the cloud and rain drop populations, as well as for the effect of collision-coalescence between the cloud and rain drop populations.

Sedimentation of cloud and rain droplets vertically redistributes aerosol number and mass: in the process, the 
aerosol number in cloud and rain droplets is transported at the same rate as the cloud and rain drop number, respectively, while the aerosol mass, resolved by aerosol mode and chemical composition, is transported vertically at the same relative rate as the cloud and rain drop water mass. Sedimentation of cloud and rain water to the surface results in wet deposition of the particles contained therein, and their removal from the system.

After completion of the cloud microphysics scheme, its aerosol quantities are converted to those used by the WRF/Chem MADE aerosol module: the number of particles residing in cloud and rain water is summed to give the number of particles in liquid water. Aerosol mass residing in cloud and rain water is summed to give the aerosol mass residing in liquid water, with the information on aerosol mode and chemical composition intact. The number of particles in liquid water and the number of interstitial particles that were re-generated by evaporation of cloud droplets are partitioned onto the three MADE aerosol modes. This partitioning can be calculated from the number of particles in the three modes in liquid water before the call to the cloud microphysics scheme, and from the number of particles activated from each of the modes in the cloud microphysics scheme. In the present implementation, however, it is assumed that the growth of cloud-borne Aitken mode particles resulting from collision-coalescence of droplets and from aqueous chemistry will produce accumulation mode particles upon evaporation of the droplets. Therefore, Aitken mode particles residing in liquid water are placed into the accumulation mode in liquid water, and interstitial Aitken mode particles that were re-generated due to cloud drop evaporation are placed into the interstitial accumulation mode. This treatment of mode transfer due to cloud processing is based on the notion that it is activation in the first place which is responsible for the emergence of the accumulation mode, hence being activated is a sensible criterion that a particle should belong to the accumulation mode.

Removal of interstitial Aitken mode particles by collisions with cloud droplets is described with the Fuchs expression for Brownian coagulation in Seinfeld and Pandis (1998), assuming an accommodation coefficient of unity. The calculation is simplified by using a single rate coefficient for the process, computed from the Aitken mode geometric mean diameter and the mean cloud droplet volume diameter. The mass of the interstitial Aitken mode particles that collide with cloud droplets is added to the mass of accumulation mode particles that reside in liquid water. Removal of interstitial accumulation and coarse mode particles by Brownian coagulation with cloud droplets is neglected: the rate coefficient for this process is significantly smaller than for Brownian coagulation of Aitken mode particles with cloud droplets. In addition, the coagulation rate scales with the product of the concentrations of the coagulating particle populations, but inside clean MBL clouds, interstitial accumulation and coarse mode particle concentrations are, due to activation, much lower than interstitial Aitken mode particle concentrations. Collection scavenging of interstitial aerosol by rain droplets is not accounted for in the present implementation.

\section{A2 Gas phase chemistry, aqueous phase chemistry, and cloud microphysics}

The cloud microphysics scheme (Feingold et al., 1998; Wang and Feingold, 2009) tracks the mass of gas phase species dissolved in liquid water, resolved by chemical composition, in analogy to the description of aerosol tracking in cloud and rain water mass described above: the WRF/Chem aqueous chemistry scheme (Fahey and Pandis, 2001) provides the masses of the gas phase species dissolved in liquid water, which the cloud microphysics scheme partitions into cloud and rain water components in proportion to the ratio of cloud to rain water mass. It then applies drop evaporation, collision-coalescence, and sedimentation on the dissolved species as follows: evaporation of water from cloud and rain droplets entails the evaporation of the dissolved gas phase species at the same relative rate. When water evaporation converts a given fraction of rain water mass into cloud water mass, the same fraction of dissolved mass is transferred from the rain drop to the cloud drop population. Collisioncoalescence transfers dissolved mass from cloud droplets to rain droplets at the same relative rate as water mass. Sedimentation of cloud and rain droplets vertically re-distributes the dissolved gas phase species: in the process, the mass of the dissolved gas is transported at the same relative rate as the cloud and rain water mass, respectively. Sedimentation of cloud and rain water to the surface results in wet deposition of the dissolved gas phase species. After completion of the cloud microphysics scheme, the mass of gas phase species dissolved in cloud and rain water, resolved by chemical composition, is summed to give the mass of gas phase species dissolved in liquid water. 
Appendix B

\section{Chemical species}

Table. B1. Gas phase chemical species used in this work.

\begin{tabular}{ll}
\hline Formula & Name \\
\hline $\mathrm{H}_{2}$ & Molecular hydrogen \\
$\mathrm{O}\left({ }^{3} \mathrm{P}\right)$ & Atomic oxygen (ground state) \\
$\mathrm{O}\left({ }^{1} \mathrm{D}\right)$ & Atomic oxygen (excited state) \\
$\mathrm{CH}_{4}$ & Methane \\
$\mathrm{OH}$ & Hydroxyl radical \\
$\mathrm{NH}_{3}$ & Ammonia \\
$\mathrm{H}_{2} \mathrm{O}$ & Water \\
$\mathrm{CO}$ & Carbon monoxide \\
$\mathrm{N}_{2}$ & Molecular nitrogen \\
$\mathrm{NO}$ & Nitric oxide \\
$\mathrm{HCHO}$ & Formaldehyde \\
$\mathrm{O}_{2}$ & Molecular oxygen \\
$\mathrm{HO}_{2}$ & Hydroperoxyl radical \\
$\mathrm{H}_{2} \mathrm{O}_{2}$ & Hydrogen peroxide \\
$\mathrm{CO}_{2}$ & Carbon dioxide \\
$\mathrm{NO}_{2}$ & Nitrogen dioxide \\
$\mathrm{CH}_{3} \mathrm{O}_{2}$ & Methyl peroxy radical \\
$\mathrm{O}_{3}$ & Ozone \\
$\mathrm{NO}_{3}$ & Nitrate radical \\
$\mathrm{CH}_{3} \mathrm{SCH}_{3}$ & Dimethyl sulfide (DMS) \\
$\mathrm{HNO}_{3}$ & Nitric acid \\
$\mathrm{SO}_{2}$ & Sulfur dioxide \\
$\mathrm{HNO}_{4}$ & Hydroxy nitrate \\
$\mathrm{H}_{2} \mathrm{SO}_{4}$ & Sulfuric acid \\
$\mathrm{N}_{2} \mathrm{O}_{5}$ & Dinitrogen pentoxide \\
\hline &
\end{tabular}

\section{Appendix C}

\section{Gas phase reactions and rate coefficients}

Table. C1. Gas phase reactions (from the RADM2 chemical mechanism, Stockwell et al., 1990) used in this work with a rate coef-

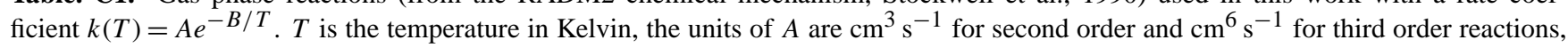
the units of $B$ are Kelvin.

\begin{tabular}{|c|c|c|c|}
\hline Reaction & $A$ & $B$ & Reference \\
\hline $\mathrm{O}\left({ }^{3} \mathrm{P}\right)+\mathrm{NO}_{2} \rightarrow \mathrm{NO}+\mathrm{O}_{2}$ & $6.5 \times 10^{-12}$ & -120 & DeMore et al. (1988) \\
\hline $\mathrm{O}\left({ }^{1} \mathrm{D}\right)+\mathrm{N}_{2} \rightarrow \mathrm{O}\left({ }^{3} \mathrm{P}\right)+\mathrm{N}_{2}$ & $1.8 \times 10^{-11}$ & -110 & DeMore et al. (1988) \\
\hline $\mathrm{O}\left({ }^{1} \mathrm{D}\right)+\mathrm{O}_{2} \rightarrow \mathrm{O}\left({ }^{3} \mathrm{P}\right)+\mathrm{O}_{2}$ & $3.2 \times 10^{-11}$ & -70 & DeMore et al. (1988) \\
\hline $\mathrm{O}\left({ }^{1} \mathrm{D}\right)+\mathrm{H}_{2} \mathrm{O} \rightarrow 2 \mathrm{OH}$ & $2.2 \times 10^{-10}$ & 0 & DeMore et al. (1988) \\
\hline $\mathrm{O}_{3}+\mathrm{NO} \rightarrow \mathrm{NO}_{2}+\mathrm{O}_{2}$ & $2.0 \times 10^{-12}$ & 1400 & DeMore et al. (1988) \\
\hline $\mathrm{O}_{3}+\mathrm{OH} \rightarrow \mathrm{HO}_{2}+\mathrm{O}_{2}$ & $1.6 \times 10^{-12}$ & 940 & DeMore et al. (1988) \\
\hline $\mathrm{O}_{3}+\mathrm{HO}_{2} \rightarrow \mathrm{OH}+2 \mathrm{O}_{2}$ & $1.1 \times 10^{-14}$ & 500 & DeMore et al. (1988) \\
\hline $\mathrm{HO}_{2}+\mathrm{NO} \rightarrow \mathrm{NO}_{2}+\mathrm{OH}$ & $3.7 \times 10^{-12}$ & -240 & DeMore et al. (1988) \\
\hline $\mathrm{H}_{2} \mathrm{O}_{2}+\mathrm{OH} \rightarrow \mathrm{HO}_{2}+\mathrm{H}_{2} \mathrm{O}$ & $3.3 \times 10^{-12}$ & 200 & DeMore et al. (1988) \\
\hline $\mathrm{NO}+\mathrm{NO}+\mathrm{O}_{2} \rightarrow 2 \mathrm{NO}_{2}$ & $3.3 \times 10^{-39}$ & -530 & Atkinson and Lloyd (1984) \\
\hline $\mathrm{O}_{3}+\mathrm{NO}_{2} \rightarrow \mathrm{NO}_{3}+\mathrm{O}_{2}$ & $1.4 \times 10^{-13}$ & 2500 & DeMore et al. (1988) \\
\hline $\mathrm{NO}_{3}+\mathrm{NO} \rightarrow 2 \mathrm{NO}_{2}$ & $1.7 \times 10^{-11}$ & -150 & DeMore et al. (1988) \\
\hline $\mathrm{NO}_{3}+\mathrm{NO}_{2} \rightarrow \mathrm{NO}+\mathrm{NO}_{2}+\mathrm{O}_{2}$ & $2.5 \times 10^{-14}$ & 1230 & Atkinson and Lloyd (1984) \\
\hline $\mathrm{NO}_{3}+\mathrm{HO}_{2} \rightarrow \mathrm{HNO}_{3}+\mathrm{O}_{2}$ & $2.5 \times 10^{-12}$ & & Cantrell et al. (1985) \\
\hline $\mathrm{N}_{2} \mathrm{O}_{5}+\mathrm{H}_{2} \mathrm{O} \rightarrow 2 \mathrm{HNO}_{3}$ & $2.0 \times 10^{-21}$ & & DeMore et al. (1988) \\
\hline $\mathrm{OH}+\mathrm{HNO}_{4} \rightarrow \mathrm{NO}_{2}+\mathrm{H}_{2} \mathrm{O}+\mathrm{O}_{2}$ & $1.3 \times 10^{-12}$ & -380 & DeMore et al. (1988); Uselman et al. (1979) \\
\hline $\mathrm{OH}+\mathrm{HO}_{2} \rightarrow \mathrm{H}_{2} \mathrm{O}+\mathrm{O}_{2}$ & $4.6 \times 10^{-11}$ & -230 & DeMore et al. (1988) \\
\hline $\mathrm{HCHO}+\mathrm{OH}\left(+\mathrm{O}_{2}\right) \rightarrow \mathrm{HO}_{2}+\mathrm{CO}+\mathrm{H}_{2} \mathrm{O}$ & $9.0 \times 10^{-12}$ & & Atkinson (1986) \\
\hline $\mathrm{CH}_{3} \mathrm{O}_{2}+\mathrm{NO}\left(+\mathrm{O}_{2}\right) \rightarrow \mathrm{HCHO}+\mathrm{HO}_{2}+\mathrm{NO}_{2}$ & $4.2 \times 10^{-12}$ & -180 & DeMore et al. (1988) \\
\hline $\mathrm{HCHO}+\mathrm{NO}_{3}\left(+\mathrm{O}_{2}\right) \rightarrow \mathrm{HO}_{2}+\mathrm{HNO}_{3}+\mathrm{CO}$ & $6.0 \times 10^{-13}$ & 2058 & Cantrell et al. (1985) \\
\hline $\mathrm{CH}_{3} \mathrm{O}_{2}+\mathrm{CH}_{3} \mathrm{O}_{2} \rightarrow 1.5 \mathrm{HCHO}+\mathrm{HO}_{2}+\ldots$ & $1.9 \times 10^{-13}$ & -220 & DeMore et al. (1988); Carter et al. (1986) \\
\hline
\end{tabular}


Table. C2. Gas phase reactions (from the RADM2 chemical mechanism, Stockwell et al., 1990) used in this work with a rate coefficient $k(T,[\mathrm{M}])=k_{0}(T)[\mathrm{M}] /\left(1+k_{0}(T)[\mathrm{M}] / k_{\infty}(T)\right) 0.6^{\left\{1+\left[\log _{10}\left(k_{0}(T)[\mathrm{M}] / k_{\infty}(T)\right)\right]^{2}\right\}^{-1}}$, where $k_{0}(T)=k_{0}^{300}(T / 300)^{-n}$ and $k_{\infty}(T)=k_{\infty}^{300}(T / 300)^{-m}$ (DeMore et al., 1988). $T$ is the temperature in Kelvin and [M] the concentration of air molecules in $\mathrm{cm}^{-3}$. The units of $k_{0}^{300}$ are $\mathrm{cm}^{6} \mathrm{~s}^{-1}$, and of $k_{\infty}^{300} \mathrm{~cm}^{3} \mathrm{~s}^{-1}$.

\begin{tabular}{lllll}
\hline Reaction & $k_{0}^{300}$ & $n$ & $k_{\infty}^{300}$ & $m$ \\
\hline $\mathrm{HO}_{2}+\mathrm{NO}_{2} \rightarrow \mathrm{HNO}_{4}$ & $1.8 \times 10^{-31}$ & 3.2 & $4.7 \times 10^{-12}$ & 1.4 \\
$\mathrm{NO}_{3}+\mathrm{NO}_{2} \rightarrow \mathrm{N}_{2} \mathrm{O}_{5}$ & $2.2 \times 10^{-30}$ & 4.3 & $1.5 \times 10^{-12}$ & 0.5 \\
$\mathrm{OH}+\mathrm{NO}_{2} \rightarrow \mathrm{HNO}_{3}$ & $2.6 \times 10^{-30}$ & 3.2 & $2.4 \times 10^{-11}$ & 1.3 \\
$\mathrm{OH}+\mathrm{SO}_{2}\left(+\mathrm{H}_{2} \mathrm{O}+\mathrm{O}_{2}\right) \rightarrow \mathrm{H}_{2} \mathrm{SO}_{4}+\mathrm{HO}_{2}$ & $3.0 \times 10^{-31}$ & 3.3 & $1.5 \times 10^{-12}$ & 0.0 \\
\hline
\end{tabular}

Table. C3. Unimolecular gas phase reactions and rate coefficients (from the RADM2 chemical mechanism, Stockwell et al., 1990) used in this work, that are calculated from equilibria. The rate coefficient is calculated as $k(T)=k_{\mathrm{r}}(T) A e^{-B / T}$ (DeMore et al., 1988), where $k_{\mathrm{r}}(T)$ is the rate coefficient of the corresponding formation reaction (Table C2), and $T$ the temperature in Kelvin. The units of $A$ are $\mathrm{cm}^{-3}$, the units of $B$ are Kelvin.

\begin{tabular}{lll}
\hline Reaction & $A$ & $B$ \\
\hline $\mathrm{HNO}_{4} \rightarrow \mathrm{HO}_{2}+\mathrm{NO}_{2}$ & $4.76 \times 10^{26}$ & 10900 \\
$\mathrm{~N}_{2} \mathrm{O}_{5} \rightarrow \mathrm{NO}_{2}+\mathrm{NO}_{3}$ & $9.09 \times 10^{26}$ & 11200 \\
\hline
\end{tabular}

Table. C4. Gas phase reactions and rate coefficients (from the RADM2 chemical mechanism, Stockwell et al., 1990) used in this work with special rate expressions. $T$ is the temperature in Kelvin and $[\mathrm{M}]$ the concentration of air molecules in $\mathrm{cm}^{-3}$.

\begin{tabular}{lll}
\hline Reaction & Rate coefficient $\left(\mathrm{cm}^{3} \mathrm{~s}^{-1}\right)$ & Reference \\
\hline $\mathrm{O}\left({ }^{3} \mathrm{P}\right)+\mathrm{O}_{2} \rightarrow \mathrm{O}_{3}$ & $6 \times 10^{-34}(T / 300)^{-2.3}[\mathrm{M}]$ & DeMore et al. (1988) \\
$\mathrm{HO}_{2}+\mathrm{HO}_{2} \rightarrow \mathrm{H}_{2} \mathrm{O}_{2}+\mathrm{O}_{2}$ & $2.2 \times 10^{-13} e^{620 / T}+1.9 \times 10^{-33} e^{980 / T}[\mathrm{M}]$ & $\begin{array}{l}\text { Sander et al. (1982) } \\
\text { Kirtcher and Sander (1984) }\end{array}$ \\
$\mathrm{HO}_{2}+\mathrm{HO}_{2}+\mathrm{H}_{2} \mathrm{O} \rightarrow \mathrm{H}_{2} \mathrm{O}_{2}+\ldots$ & $3.08 \times 10^{-34} e^{2820 / T}+2.66 \times 10^{-54} e^{3180 / T}[\mathrm{M}]$ & Sander et al. (1982) \\
$\mathrm{OH}+\mathrm{HNO}_{3} \rightarrow \mathrm{NO}_{3}+\mathrm{H}_{2} \mathrm{O}$ & $k=k_{1}+k_{3} /\left(1+k_{3} / k_{2}\right)$ & DeMore et al. (1988) \\
& $k_{1}=7.2 \times 10^{-15} e^{785 / T}$ & \\
& $k_{2}=4.1 \times 10^{-16} e^{1440 / T}$ & \\
$\mathrm{CO}+\mathrm{OH}\left(+\mathrm{O}_{2}\right) \rightarrow \mathrm{HO}_{2}+\mathrm{CO}_{2}$ & $1.5 \times 10^{-13}\left(1+2.439 \times 10^{-20}[\mathrm{M}]\right)$ & DeMore et al. (1988) \\
$\mathrm{CH}+\mathrm{OH}\left(+\mathrm{O}_{2}\right) \rightarrow \mathrm{CH}_{3} \mathrm{O}_{2}+\mathrm{H}_{2} \mathrm{O}$ & $6.95 \times 10^{-18} T^{2} e^{(-1280 / T)}$ & Atkinson (1986) \\
\hline
\end{tabular}

Table. C5. DMS oxidation reactions. $T$ is the temperature in Kelvin.

\begin{tabular}{lll}
\hline Reaction & Rate coefficient $\left(\mathrm{cm}^{3} \mathrm{~s}^{-1}\right)$ & Reference \\
\hline $\mathrm{CH}_{3} \mathrm{SCH}_{3}+\mathrm{OH} \rightarrow \mathrm{SO}_{2}+\ldots$ & $\left(T \times e^{-234 / T}+8.46 \times 10^{-10} e^{7230 / T}\right.$ & Hynes et al. (1986) \\
& $\left.+2.68 \times 10^{-10} e^{7810 / T}\right) /$ & \\
& $\left(1.04 \times 10^{11} T+88.1 e^{7460 / T}\right)$ & \\
$\mathrm{CH}_{3} \mathrm{SCH}_{3}+\mathrm{NO}_{3} \rightarrow \mathrm{SO}_{2}+\mathrm{HNO}_{3}+\ldots$ & $1.9 \times 10^{-13} e^{520 / T}$ & Atkinson et al. (1992) \\
\hline
\end{tabular}




\section{Appendix D}

\section{Photodissociation reactions, cross sections, and quantum yields}

Table. D1. Photodissociation reactions, cross sections, and quantum yields (from the RADM2 chemical mechanism, Stockwell et al., 1990) used in this work.

\begin{tabular}{|c|c|c|}
\hline Reaction & Cross section & Quantum yield \\
\hline $\mathrm{NO}_{2}+\mathrm{h} v \rightarrow \mathrm{O}\left({ }^{3} \mathrm{P}\right)+\mathrm{NO}$ & Bass et al. (1976); Davenport (1978) & Gardner et al. (1987) \\
\hline $\mathrm{O}_{3}+\mathrm{h} v \rightarrow \mathrm{O}\left({ }^{1} \mathrm{D}\right)+\mathrm{O}_{2}$ & DeMore et al. (1988) & Moortgat and Kudszus (1978), scaled by 0.9 \\
\hline $\mathrm{O}_{3}+\mathrm{h} v \rightarrow \mathrm{O}\left({ }^{3} \mathrm{P}\right)+\mathrm{O}_{2}$ & DeMore et al. (1988) & Total yield for $\mathrm{O}\left({ }^{1} \mathrm{D}\right)$ and $\mathrm{O}\left({ }^{3} \mathrm{P}\right)$ assumed unity \\
\hline $\mathrm{HNO}_{3}+\mathrm{h} v \rightarrow \mathrm{OH}+\mathrm{NO}_{2}$ & Molina and Molina (1981) & Assumed $=1$ over $U V$ absorption range \\
\hline $\mathrm{HNO}_{4}+\mathrm{h} v \rightarrow \mathrm{HO}_{2}+\mathrm{NO}_{2}$ & Molina and Molina (1981) & Assumed $=1$ over $\mathrm{UV}$ absorption range \\
\hline $\mathrm{NO}_{3}+\mathrm{h} v \rightarrow \mathrm{NO}+\mathrm{O}_{2}$ & $\begin{array}{l}\lambda<570 \mathrm{~nm} \text { Graham and Johnston (1978), } \\
\lambda>570 \mathrm{~nm} \text { average of Graham and Johnston (1978) } \\
\text { and Ravishankara and Wine (1983) }\end{array}$ & $\begin{array}{l}\text { Graham and Johnston (1978); } \\
\text { Magnotta and Johnston (1980), } \\
\text { scaled to a total yield of unity }\end{array}$ \\
\hline $\mathrm{NO}_{3}+\mathrm{h} v \rightarrow \mathrm{NO}_{2}+\mathrm{O}\left({ }^{3} \mathrm{P}\right)$ & $\begin{array}{l}\lambda<570 \mathrm{~nm} \text { Graham and Johnston (1978), } \\
\lambda>570 \mathrm{~nm} \text { average of Graham and Johnston (1978) } \\
\text { and Ravishankara and Wine (1983) }\end{array}$ & $\begin{array}{l}\text { Graham and Johnston (1978); } \\
\text { Magnotta and Johnston (1980), } \\
\text { scaled to a total yield of unity }\end{array}$ \\
\hline $\mathrm{H}_{2} \mathrm{O}_{2}+\mathrm{h} v \rightarrow 2 \mathrm{OH}+\ldots$ & $\begin{array}{l}\text { Average of Lin et al. (1978) and } \\
\text { Molina and Molina (1981) }\end{array}$ & Assumed $=1$ over UV absorption range \\
\hline $\mathrm{HCHO}+\mathrm{h} v \rightarrow \mathrm{CO}+\mathrm{H}_{2}$ & $\begin{array}{l}\text { Average of Moortgat et al. }(1978,1983) \\
\text { and Bass et al. (1980) }\end{array}$ & $\begin{array}{l}\text { Horowitz and Calvert (1978); } \\
\text { Moortgat et al. (1983) } \\
\text { see Stockwell et al. (1990) } \\
\text { for pressure dependence }\end{array}$ \\
\hline $\mathrm{HCHO}+\mathrm{h} v\left(+2 \mathrm{O}_{2}\right) \rightarrow 2 \mathrm{HO}_{2}+\mathrm{CO}$ & $\begin{array}{l}\text { Average of Moortgat et al. }(1978,1983) \\
\text { and Bass et al. (1980) }\end{array}$ & $\begin{array}{l}\text { Horowitz and Calvert (1978); } \\
\text { Moortgat et al. (1983), } \\
\text { see Stockwell et al. (1990) } \\
\text { for pressure dependence }\end{array}$ \\
\hline
\end{tabular}

Acknowledgements. This work was supported by the National Oceanic and Atmospheric Administration's Climate Goal (NOAA OAR Climate Program Office grant NA08OAR4310566). The aircraft measurements of aerosol concentration and composition were supported by the National Science Foundation grants ATM0745368 and ATM-0745986; the aircraft sulfur dioxide and DMS measurements were supported by the National Science Foundation grant ATM-0749088. We appreciate the use of the shipboard DMS flux data generated by the Huebert group at the University of Hawaii, with support from the National Science Foundation grants ATM-0241611, ATM-0526341, and ATM-0745337. The C-130 aircraft time was provided by the National Center for Atmospheric Research (NCAR) which is sponsored by the National Science Foundation. We thank the team of scientists, engineers, and support staff for their efforts in making VOCALS-REx a great success; Robert Wood (University of Washington) for providing assistance in interpreting VOCALS-REx data, and A. R. Ravishankara (NOAA ESRL Chemical Sciences Division) for helpful discussions. The NOAA ESRL High Performance Computing Systems team is gratefully acknowledged for computational and technical support.

Edited by: H. Coe

\section{References}

Ackerman, A. S., Toon, O. B. and Hobbs, P. V.: Dissipation of marine stratiform clouds and collapse of the marine boundary layer due to the depletion of cloud condensation nuclei by clouds, Science, 262, 226-229, doi:10.1126/science.262.5131.226, 1993.

Ackermann, I. J., Hass, H., Memmesheimer, M., Ebel, A., Binkowski, F. S., and Shankar, U.: Modal aerosol dynamics model for Europe: development and first applications, Atmos. Environ., 32, 2981-2999, doi:10.1016/S1352-2310(98)00006-5, 1998.

Agee, E. M.: Observations from space and thermal convection: a historical perspective, B. Am. Meteorol. Soc., 65, 938-949, doi:10.1175/1520-0477(1984)065<0938:OFSATC > 2.0.CO;2, 1984.

Albrecht, B. A.: Aerosols, cloud microphysics and fractional cloudiness, Science, 245, 1227-1230, doi:10.1126/science.245.4923.1227, 1989.

Andreae, M. O., Elbert, W., and de Mora, S. J.: Biogenic sulfur emissions and aerosols over the tropical South Atlantic 3. Atmospheric dimethylsulfide, aerosols and cloud condensation nuclei, J. Geophys. Res., 100, 11335-11356, doi:10.1029/94JD02828, 1995.

Atkinson, R.: Kinetics and mechanisms of the gas-phase reactions of the hydroxyl radical with organic compounds under atmospheric conditions, Chem. Rev., 86, 69-201, doi:10.1021/cr00071a004, 1986.

Atkinson, R. and Lloyd, A. C.: Evaluation of kinetic and mechanistic data for modeling of photochemical smog, J. Phys. Chem. 
Ref. Data, 13, 315-444, doi:10.1063/1.555710, 1984.

Atkinson, R., Baulch, D. L., Cox, R. A., Hampson, R. F., Kerr, J. A., and Troe, J.: Evaluated kinetic and photochemical data for atmospheric chemistry: Supplement IV, J. Phys. Chem. Ref. Data, 21, 1125-1568, doi:10.1063/1.555918, 1992.

Ayers, G. P. and Gras, J. L.: Seasonal relationship between cloud condensation nuclei and aerosol methanesulphonate in marine air, Nature, 353, 834-835, doi:10.1038/353834a0, 1991.

Ball, S. M., Hanson, D. R., Eisele, F. L., and McMurry, P. H.: Laboratory studies of particle nucleation: initial results for $\mathrm{H}_{2} \mathrm{SO}_{4}$, $\mathrm{H}_{2} \mathrm{O}$, and $\mathrm{NH}_{3}$ vapors, J. Geophys. Res., 104, 23709-23718, doi:10.1029/1999JD900411, 1999.

Bandy, A. R., Thornton, D. C., Tu, F. H., Blomquist, B. W., Nadler, W., Mitchell, G. M., and Lenschow, D. H.: Determination of the vertical flux of dimethyl sulfide by eddy correlation and atmospheric pressure ionization mass spectrometry (APIMS), J. Geophys. Res., 107, 4743, doi:10.1029/2002JD002472, 2002.

Bass, A. M., Ledford, A. E., and Laufer, A. H.: Extinction coefficients of $\mathrm{NO}_{2}$ and $\mathrm{N}_{2} \mathrm{O}_{4}$, J. Res. Natl. Bur. Stand. Sect. A, 80, 143-166, 1976.

Bass, A. M., Glasgow, L. C., Miller, C., Jesson, J. P., and Filkin, D. L.: Temperature dependent absorption cross sections for formaldehyde $\left(\mathrm{CH}_{2} \mathrm{O}\right)$ : the effect of formaldehyde on stratospheric chlorine chemistry, Planet. Space Sci., 28, 675-679, doi:10.1016/0032-0633(80)90112-9, 1980.

Bigg, E. K. and Leck, C.: The composition of fragments of bubbles bursting at the ocean surface, J. Geophys. Res., 113, D11209, doi:10.1029/2007JD009078, 2008.

Burkholder, J. B., Curtius, J., Ravishankara, A. R., and Lovejoy, E. R.: Laboratory studies of the homogeneous nucleation of iodine oxides, Atmos. Chem. Phys., 4, 19-34, doi:10.5194/acp-4-192004, 2004.

Cantrell, C. A., Stockwell, W. R., Anderson, L. G., Busarow, K. L., Perner, D., Schmeltekopf, A., Calvert, J. G., and Johnston, H. S.: Kinetic study of the nitrate free radical $\left(\mathrm{NO}_{3}\right)$-formaldehyde reaction and its possible role in nighttime tropospheric chemistry, $\mathrm{J}$. Phys. Chem., 89, 139-146, doi:10.1021/j100247a031, 1985.

Capaldo, K. P., Kasibhatla, P., and Pandis, S. N.: Is aerosol production within the remote marine boundary layer sufficient to maintain observed concentrations?, J. Geophys. Res., 104, 34833500, doi:10.1029/1998JD100080, 1999.

Carter, W. P. L., Lurmann, F. W., Atkinson, R., and Lloyd, A. C.: Development and testing of a surrogate species chemical reaction mechanism, EPA/600/S3-86/031, Atmospheric Sciences Research Laboratory, Environmental Protection Agency, Research Triangle Park, NC, USA, 1986.

Chang, J. S., Binkowski, F. S., Seaman, N. L., McHenry, J. N., Samson, P. J., Stockwell, W. R., Walcek, C. J., Madronich, S., Middleton, P. B., Pleim, J. E., and Lansford, H. H.: The regional acid deposition model and engineering model, State-ofScience/Technology Report 4, National Acid Precipitation Assessment Program, Washington, DC, USA, 1989.

Chapman, E. G., Gustafson Jr., W. I., Easter, R. C., Barnard, J. C., Ghan, S. J., Pekour, M. S., and Fast, J. D.: Coupling aerosolcloud-radiative processes in the WRF-Chem model: Investigating the radiative impact of elevated point sources, Atmos. Chem. Phys., 9, 945-964, doi:10.5194/acp-9-945-2009, 2009.

Charlson, R. J., Lovelock, J. E., Andreae, M. O., and Warren, S. G.:
Oceanic phytoplankton, atmospheric sulphur, cloud albedo and climate change, Nature, 326, 655-661, doi:10.1038/326655a0, 1987.

Clarke, A. D. and Kapustin, V. N.: A Pacific aerosol survey. Part I: A decade of data on particle production, transport, evolution, and mixing in the troposphere, J. Atmos. Sci., 52, 363-382, doi:10.1175/1520-0469(2002)059<0363:APASPI>2.0.CO;2, 2002.

Clarke, A. D., Davis, D., Kapustin, V. N., Eisele, F., Chen, G., Paluch, I., Lenschow, D., Bandy, A. R., Thornton, D., Moore, K., Mauldin, L., Tanner, D., Litchy, M., Carroll, M. A., Collins, J., and Albercook, G.: Particle nucleation in the tropical boundary layer and its coupling to marine sulphur sources, Science, 282, 89-92, doi:10.1126/science.282.5386.89, 1998.

Clarke, A. D., Eisele, F., Kapustin, V. N., Moore, K., Tanner, D., Mauldin, L., Litchy, M., Lienert, B., Carroll, M. A., and Albercook, G.: Nucleation in the equatorial free troposphere: Favorable environments during PEM-Tropics, J. Geophys. Res., 104, 5735-5744, doi:10.1029/98JD02303, 1999.

Clarke, A. D., Owens, S. R., and Zhou, J.: An ultrafine sea-salt flux from breaking waves: Implications for cloud condensation nuclei in the remote marine atmosphere, J. Geophys. Res., 111, 6202, doi:10.1029/2005JD006565, 2006

Coffman, D. J. and Hegg, D. A.: A preliminary study of the effect of ammonia on particle nucleation in the marine boundary layer, J. Geophys. Res., 100, 7147-7160, doi:10.1029/94JD03253, 1995.

Collins, W. D., Rasch, P. J., Boville, B. A., Hack, J. J., McCaa, J. R., Williamson, D. L., Kiehl, J. T., Briegleb, B., Bitz, C., Lin, S.J., Zhang, M., and Dai, Y.: Description of the NCAR Community Atmosphere Model (CAM 3.0), Tech. Rep. NCAR/TN464+STR, National Center for Atmospheric Research, Boulder, CO, USA, http://www.cesm.ucar.edu/models/atm-cam/docs/ description/ (last access: January 2011), 2004.

Curtius, J., Froyd, K. D., and Lovejoy, E. R.: Cluster ion thermal decomposition (I): Experimental kinetics study and ab initio calculations for $\mathrm{HSO}_{4}^{-}\left(\mathrm{H}_{2} \mathrm{SO}_{4}\right)_{(\mathrm{x})}\left(\mathrm{HNO}_{3}\right)_{(\mathrm{y})}$, J. Phys. Chem. A, 105, 10867-10873, doi:10.1021/jp0124950, 2001.

Damian, V., Sandu, A., Damian, M., Potra, F., and Carmichael, G. R.: The kinetic preprocessor KPP - a software environment for solving chemical kinetics, Comp. Chem. Eng., 26, 1567-1579, doi:10.1016/S0098-1354(02)00128-X, 2002.

Davenport, J. E.: Determination of $\mathrm{NO}_{2}$ photolysis parameters for stratospheric modeling, Final Rep. FAA/EQ-78-14, High Altitude Program, Office of Environmental Quality, Federal Aviation Administration, Washington, DC, USA, 1978.

De Bruyn, W. J., Swartz, E., Hu, J. H., Shorter, J. A., Davidovits, P., Worsnop, D. R., Zahniser, M. S., and Kolb, C. E.: Henry's law solubilities and Śetchenow coefficients for biogenic reduced sulfur species obtained from gas-liquid uptake measurements, J. Geophys. Res., 100, 7245-7252, doi:10.1029/95JD00217, 1995.

DeMore, W. B., Molina, M. J., Sander, S. P., Golden, D. M., Hampson, R. F., Kurylo, M. J., Howard, C. J., and Ravishankara, A. R.: Chemical kinetics and photochemical data for use in stratospheric modeling evaluation Number 8, JPL Publication 87-41, Jet Propulsion Laboratory, National Aeronautics and Space Administration, California Institute of Technology, Pasadena, California, USA, 1988.

DOE: Handbook of methods for the analysis of the various param- 
eters of the carbon dioxide system in sea water, version 2.13, ORNL/CDIAC-74, chap. 5 - Physical and thermodynamic data, p. 11, US Department of Energy, Oak Ridge National Labporatory, Carbon Dioxide Information and Analysis Center, 1994.

Emmons, L. K., Walters, S., Hess, P. G., Lamarque, J.-F., Pfister, G. G., Fillmore, D., Granier, C., Guenther, A., Kinnison, D., Laepple, T., Orlando, J., Tie, X., Tyndall, G., Wiedinmyer, C., Baughcum, S. L., and Kloster, S.: Description and evaluation of the Model for Ozone and Related chemical Tracers, version 4 (MOZART-4), Geosci. Model Dev., 3, 43-67, doi:10.5194/gmd3-43-2010, 2010.

Ervens, B., Feingold, G., and Kreidenweis, S. M.: Influence of water-soluble organic carbon on cloud drop number concentration, J. Geophys. Res., 110, D18211, doi:10.1029/2004JD005634, 2005.

Fahey, K. M. and Pandis, S. N.: Optimizing model performance: variable size resolution in cloud chemistry modeling, Atmos. Environ., 35, 4471-4478, doi:10.1016/S1352-2310(01)00224-2, 2001.

Faloona, I., Conley, S. A., Blomquist, B., Clarke, A. D., Kapustin, V., Howell, S., Lenschow, D. H., and Bandy, A. R.: Sulfur dioxide in the tropical marine boundary layer: dry deposition and heterogeneous oxidation observed during the Pacific Atmospheric Sulfur Experiment, J. Atmos. Chem., 63, 13-32, doi:10.1007/s10874-010-9155-0, 2010.

Feingold, G.: Modeling of the first indirect effect: Analysis of measurement requirements, Geophys. Res. Lett., 30, 1997, doi:10.1029/2003GL017967, 2003.

Feingold, G. and Kreidenweis, S. M.: Cloud processing of aerosol as modeled by a large eddy simulation with coupled microphysics and aqueous chemistry, J. Geophys. Res., 107(D23), 4687, doi:10.1029/2002JD002054, 2002.

Feingold, G., Kreidenweis, S. M., Stevens, B., and Cotton, W. R.: Numerical simulations of stratocumulus processing of cloud condensation nuclei through collision-coalescence, J. Geophys. Res., 101, 21391-21402, doi:10.1029/96JD01552, 1996.

Feingold, G., Walko, R. L., Stevens, B., and Cotton, W. R.: Simulations of marine stratocumulus using a new microphysical parameterization scheme, Atmos. Res., 47-48, 505-528, doi:10.1016/S0169-8095(98)00058-1, 1998.

Flossmann, A. I., Hall, W. D., and Pruppacher, H. R.: A theoretical study of the wet removal of atmospheric pollutants. Part I: The redistribution of aerosol particles captured through nucleation and impaction scavenging by growing cloud drops, J. Atmos. Sci., 42, 583-606, doi:10.1175/15200469(1985)042<0583:ATSOTW>2.0.CO;2, 1985.

Froyd, K. D. and Lovejoy, E. R.: Experimental thermodynamics of cluster ions composed of $\mathrm{H}_{2} \mathrm{SO}_{4}$ and $\mathrm{H}_{2} \mathrm{O}$. 2. Measurements and ab initio structures of negative ions, J. Phys. Chem. A, 107, 9812-9824, doi:10.1021/jp0278059, 2003.

Fry, J. L., Kiendler-Scharr, A., Rollins, A. W., Wooldridge, P. J., Brown, S. S., Fuchs, H., Dubé, W., Mensah, A., dal Maso, M., Tillmann, R., Dorn, H.-P., Brauers, T., and Cohen, R. C.: Organic nitrate and secondary organic aerosol yield from $\mathrm{NO}_{3}$ oxidation of $\beta$-pinene evaluated using a gas-phase kinetics/aerosol partitioning model, Atmos. Chem. Phys., 9, 14311449, doi:10.5194/acp-9-1431-2009, 2009.

Fuentes, E., Coe, H., Green, D., de Leeuw, G., and McFiggans, G.: On the impacts of phytoplankton-derived organic matter on the properties of the primary marine aerosol - Part 1: Source fluxes, Atmos. Chem. Phys., 10, 9295-9317, doi:10.5194/acp-10-92952010, 2010.

Gardner, E. P., Sperry, P. D., and Calvert, J. G.: Primary quantum yields of $\mathrm{NO}_{2}$ photodissociation, J. Geophys. Res., 92, 66426652, doi:10.1029/JD092iD06p06642, 1987.

Graham, R. A. and Johnston, H. S.: The photochemistry of the $\mathrm{NO}_{3}$ and the kinetics of the $\mathrm{N}_{2} \mathrm{O}_{5}-\mathrm{O}_{3}$ system, J. Phys. Chem., 82, 254-268, doi:10.1021/j100492a002, 1978.

Gray, B. A., Wang, Y., Gu, D., Bandy, A., Mauldin, L., Clarke, A. D., Alexander, B., and Davis, D.: Sources, transport, and sinks of $\mathrm{SO}_{2}$ over the equatorial Pacific during the $\mathrm{Pa}-$ cific Atmospheric Sulfur Experiment, J. Atmos. Chem., 1-27, doi:10.1007/s10874-010-9177-7, 2010.

Grell, G. A., Peckham, S. E., Schmitz, R., McKeen, S. A., Frost, G., Skamarock, W. C., and Eder, B.: Fully coupled "online" chemistry within WRF model, Atmos. Environ., 39, 6957-6975, doi:10.1016/j.atmosenv.2005.04.027, 2005.

Hanson, D. R. and Lovejoy, E. R.: Measurement of the thermodynamics of the hydrated dimer and trimer of sulfuric acid, J. Phys. Chem. A, 110, 9525-9528, doi:10.1021/jp062844w, 2006.

Heintzenberg, J., Birmili, W., Wiedensohler, A., Nowak, A., and Tuch, T.: Structure, variability and persistence of the submicrometre marine aerosol, Tellus B, 56, 357-367, doi:10.1111/j.1600-0889.2004.00115.x, 2004.

Horowitz, A. and Calvert, J. G.: The quantum efficiency of the primary processes in formaldehyde photolysis at $3130 \AA$ and $25^{\circ} \mathrm{C}$, Int. J. Chem. Kin., 10, 713-732, doi:10.1002/kin.550100706, 1978.

Huebert, B. J., Blomquist, B. W., Hare, J. E., Fairall, C. W., Johnson, J. E., and Bates, T. S.: Measurement of the sea-air DMS flux and transfer velocity using eddy correlation, Geophys. Res. Lett., 31, L23113, doi:10.1029/2004GL021567, 2004.

Hynes, A. J., Wine, P. H., and Semmes, D. H.: Kinetics and mechanisms of $\mathrm{OH}$ reactions with organic sulphides, J. Phys. Chem., 90, 4148-4156, doi:10.1021/j100408a062, 1986.

Katoshevski, D., Nenes, A., and Seinfeld, J. H.: A study of processes governing the maintenance of aerosols in the marine boundary layer, J. Aerosol Sci., 30, 503-532, doi:10.1016/S0021-8502(98)00740-X, 1999.

Kazil, J. and Lovejoy, E. R.: A semi-analytical method for calculating rates of new sulfate aerosol formation from the gas phase, Atmos. Chem. Phys., 7, 3447-3459, doi:10.5194/acp-7-3447-2007, 2007.

Kazil, J., Stier, P., Zhang, K., Quaas, J., Kinne, S., O’Donnell, D., Rast, S., Esch, M., Ferrachat, S., Lohmann, U., and Feichter, J.: Aerosol nucleation and its role for clouds and Earth's radiative forcing in the aerosol-climate model ECHAM5-HAM, Atmos. Chem. Phys., 10, 10733-10752, doi:10.5194/acp-1010733-2010, 2010.

King, W. D., Parkin, D. A., and Handsworth, R. J.: A hot-wire liquid water device having fully calculable response characteristics, J. Appl. Meteorol., 17, 1809-1813, doi:10.1175/15200450(1978)017<1809:AHWLWD>2.0.CO;2, 1978.

Kirtcher, C. C. and Sander, S. P.: Kinetics and mechanism of $\mathrm{HO}_{2}$ and $\mathrm{DO}_{2}$ disproportionations, J. Phys. Chem., 88, 2082-2091, doi:10.1021/j150654a029, 1984.

Kokkola, H., Hommel, R., Kazil, J., Niemeier, U., Partanen, A.-I., Feichter, J., and Timmreck, C.: Aerosol microphysics modules in 
the framework of the ECHAM5 climate model intercomparison under stratospheric conditions, Geosci. Model Dev., 2, 97-112, doi:10.5194/gmd-2-97-2009, 2009.

Kulmala, M., Dal Maso, M., Mäkelä, J. M., Pirjola, L., Väkevä, M., Aalto, P., Miikkulainen, P., Hämeri, K., and O'Dowd, C. D.: On the formation, growth and composition of nucleation mode particles, Tellus B, 53, 479-490, doi:10.1034/j.16000889.2001.530411.x, 2001.

Kulmala, M., Lehtinen, K. E. J., and Laaksonen, A.: Cluster activation theory as an explanation of the linear dependence between formation rate of $3 \mathrm{~nm}$ particles and sulphuric acid concentration, Atmos. Chem. Phys., 6, 787 793, doi:10.5194/acp-6-787-2006, 2006.

Kurtén, T., Loukonen, V., Vehkamäki, H., and Kulmala, M.: Amines are likely to enhance neutral and ion-induced sulfuric acid-water nucleation in the atmosphere more effectively than ammonia, Atmos. Chem. Phys., 8, 4095-4103, doi:10.5194/acp8-4095-2008, 2008.

Leck, C. and Bigg, E. K.: Source and evolution of the marine aerosol - a new perspective, Geophys. Res. Lett., 32, L19803, doi:10.1029/2005GL023651, 2005.

Lewis, E. R. and Schwartz, S. E.: Sea Salt Aerosol Production: Mechanisms, Methods, Measurements and Models - A Critical Review, American Geophysical Union, Washington, DC, 2004.

Lin, C. L., Rohatgi, N. K., and Demore, W. B.: Ultraviolet absorption cross sections of hydrogen peroxide, Geophys. Res. Lett., 5, 113-115, doi:10.1029/GL005i002p00113, 1978.

Lovejoy, E. R., D. R. Hanson, and L. G. Huey: Kinetics and products of the gas-phase reaction of $\mathrm{SO}_{3}$ with water. J. Phys. Chem., 100, 19911-19916, doi:10.1021/jp962414d, 1996.

Lovejoy, E. R., Curtius, J., and Froyd, K. D.: Atmospheric ioninduced nucleation of sulfuric acid and water, J. Geophys. Res., 109, D08204, doi:10.1029/2003JD004460, 2004.

Madronich, S. and Flocke, S.: Handbook of Environmental Chemistry, Chap. The role of solar radiation in atmospheric chemistry, Springer-Verlag, Heidelberg, 1-26, 1999.

Magnotta, F. and Johnston, H. S.: Photodissociation quantum yields for the $\mathrm{NO}_{3}$ free radical, Geophys. Res. Lett., 7, 769-772, doi:10.1029/GL007i010p00769, 1980.

Mäkelä, J. M., Ylikoivisto, S., Hiltunen, V., Seidl, W., Swietlicki, E., Teinilä, K., Sillanpää, M., Koponen, I. K., Paatero, J., Rosman, K., and Hämeri, K.: Chemical composition of aerosol during particle formation events in boreal forest, Tellus B, 53, 380-393, doi:10.1034/j.1600-0889.2001.530405.x, 2001.

Mitra, S. K., Brinkmann, J., and Pruppacher, H. R.: A wind tunnel study on the drop-to-particle conversion, J. Aerosol Sci., 23, 245-256, doi:10.1016/0021-8502(92)90326-Q, 1992.

Modini, R. L., Harris, B., and Ristovski, Z. D.: The organic fraction of bubble-generated, accumulation mode Sea Spray Aerosol (SSA), Atmos. Chem. Phys., 10, 2867-2877, doi:10.5194/acp10-2867-2010, 2010.

Molina, L. T. and Molina, M. J.: UV absorption cross sections of $\mathrm{HO}_{2} \mathrm{NO}_{2}$ vapor, J. Photochem., 15, 97-108, doi:10.1016/00472670(81)85002-2, 1981.

Monahan, E. C., Spiel, D. E., and Davidson, K. L.: A model of marine aerosol generation via whitecaps and wave disruption, in: Oceanic Whitecaps and Their Role in Air-Sea Exchange Processes, edited by: Monahan, E. C. and Mac Niocaill, G., D. Reidel Publishing Company, Dordrecht, Holland, 167-174, 1986.
Moortgat, G. K. and Kudszus, E.: Mathematical expression for the $\mathrm{O}\left({ }^{1} \mathrm{D}\right)$ quantum yields from the $\mathrm{O}_{3}$ photolysis as a function of temperature $(230-320 \mathrm{~K})$ and wavelength $(295-320 \mathrm{~nm})$, Geophys. Res. Lett., 5, 191-194, doi:10.1029/GL005i003p00191, 1978.

Moortgat, G. K., Klippel, W., H., M. K., Seiler, W., and Warneck, P.: Laboratory measurements of photolytic parameters for formaldehyde, Final Rep. FAA/FE-80-47, Office of Environment and Energy, Federal Aviation Administration, US Dept. of Transportation, Washington, DC, USA, 1978.

Moortgat, G. K., Seiler, W., and Warneck, P.: Photodissociation of $\mathrm{HCHO}$ in air - $\mathrm{CO}$ and $\mathrm{H}_{2}$ quantum yields at 220 and $300 \mathrm{~K}$, J. Chem. Phys., 78, 1185-1190, doi:10.1063/1.444911, 1983.

Murphy, S. M., Sorooshian, A., Kroll, J. H., Ng, N. L., Chhabra, P., Tong, C., Surratt, J. D., Knipping, E., Flagan, R. C., and Seinfeld, J. H.: Secondary aerosol formation from atmospheric reactions of aliphatic amines, Atmos. Chem. Phys., 7, 2313-2337, doi:10.5194/acp-7-2313-2007, 2007.

NOAA AGGI: NOAA Annual Greenhouse Gas Index (AGGI), http://www.esrl.noaa.gov/gmd/aggi (last access: January 2011), 2010.

O’Dowd, C. D., Jimenez, J. L., Bahreini, R., Flagan, R. C., Seinfeld, J. H., Hämeri, K., Pirjola, L., Kulmala, M., Jennings, S. G., and Hoffmann, T.: Marine aerosol formation from biogenic iodine emissions, Nature, 417, 632-636, doi:10.1038/nature00775, 2002.

Olson, J. R., Crawford, J. H., Davis, D. D., Chen, G., Avery, M. A., Barrick, J. D. W., Sachse, G. W., Vay, S. A., Sandholm, S. T., Tan, D., Brune, W. H., Faloona, I. C., Heikes, B. G., Shetter, R. E., Lefer, B. L., Singh, H. B., Talbot, R. W., and Blake, D. R.: Seasonal differences in the photochemistry of the South Pacific: a comparison of observations and model results from PEM-Tropics A and B, J. Geophys. Res., 106, 3274932766, doi:10.1029/2001JD900077, 2001.

O’Sullivan, D. W., Heikes, B. G., Snow, J., Burrow, P., Avery, M., Blake, D. R., Sachse, G. W., Talbot, R. W., Thornton, D. C., and Bandy, A. R.: Long-term and seasonal variations in the levels of hydrogen peroxide, methylhydroperoxide, and selected compounds over the Pacific Ocean, J. Geophys. Res., 109, D15S13, doi:10.1029/2003JD003689, 2004.

Petters, M. D., Snider, J. R., Stevens, B., Vali, G., Faloona, I., and Russell, L. M.: Accumulation mode aerosol, pockets of open cells, and particle nucleation in the remote subtropical $\mathrm{Pa}$ cific marine boundary layer, J. Geophys. Res., 111, D02206, doi:10.1029/2004JD005694, 2006.

Ravishankara, A. R. and Wine, P. H.: Absorption cross sections for $\mathrm{NO}_{3}$ between 565 and $673 \mathrm{~nm}$, Chem. Phys. Lett., 101, 73-78, doi:10.1016/0009-2614(83)80308-X, 1983.

Ravishankara, A. R., Rudich, Y., Talukdar, R., and Barone, S. B.: Oxidation of atmospheric reduced sulphur compounds: Perspective from laboratory studies, Philos. T. Roy. Soc. B, 352, 171181, doi:10.1098/rstb.1997.0012, 1997.

Russell, L. M., Hawkins, L. N., Frossard, A. A., Quinn, P. K., and Bates, T. S.: Carbohydrate-like composition of submicron atmospheric particles and their production from ocean bubble bursting, P. Natl. Acad. Sci., 107, 6652-6657, doi:10.1073/pnas.0908905107, 2010.

Sander, S. P., Peterson, M., Watson, R. T., and Patrick, R.: Kinetics studies of the $\mathrm{HO}_{2}+\mathrm{HO}_{2}$ and $\mathrm{DO}_{2}+\mathrm{DO}_{2}$ reactions at $298 \mathrm{~K}$, J. 
Phys. Chem., 86, 1236-1240, doi:10.1021/j100397a002, 1982.

Seinfeld, J. H. and Pandis, S. N.: Atmospheric Chemistry and Physics, John Wiley and Sons, Hoboken, NJ, 1998.

Shank, L. M., Howell, S., Clarke, A. D., Freitag, S., Brekhovskikh, V., Kapustin, V., McNaughton, C., Campos, T., and Wood, R.: Organic carbon and non-refractory aerosol over the remote Southeast Pacific: oceanic and combustion sources, Atmos. Chem. Phys. Discuss., 11, 16895-16932, doi:10.5194/acpd-1116895-2011, 2011.

Skamarock, W. C., Klemp, J. B., Dudhia, J., Gill, D. O., Barker, D. M., Duda, M. G., Huang, X.-Y., Wang, W., and Powers, J. G.: A Description of the Advanced Research WRF Version 3, Tech. Rep. NCAR/TN-475+STR, National Center for Atmospheric Research, Boulder, CO, USA, 2008.

Sommariva, R., Haggerstone, A.-L., Carpenter, L. J., Carslaw, N., Creasey, D. J., Heard, D. E., Lee, J. D., Lewis, A. C., Pilling, M. J., and Zdor, J.: $\mathrm{OH}$ and $\mathrm{HO}_{2}$ chemistry in clean marine air during SOAPEX-2, Atmos. Chem. Phys., 4, 839-856, doi:10.5194/acp-4-839-2004, 2004.

Stevens, B., Vali, G., Comstock, K., Wood, R., Van Zanten, M. C., Austin, P. H., Bretherton, C. S., and Lenschow, D. H.: Pockets of open cells and drizzle in marine stratocumulus, B. Am. Meteorol. Soc., 86, 51-57, doi:10.1175/BAMS-86-1-51, 2005a.

Stevens, B., Moeng, C.-H., Ackerman, A. S., Bretherton, C. S., Chlond, A., de Roode, S., Edwards, J., Golaz, J.-C., Jiang, H., Khairoutdinov, M., Kirkpatrick, M. P., Lewellen, D. C., Lock, A., Müller, F., Stevens, D. E., Whelan, E., and Zhu, P.: Evaluation of large-eddy simulations via observations of nocturnal marine stratocumulus, Mon. Weather Rev., 133, 1443-1462, doi:10.1175/MWR2930.1, 2005b.

Stockwell, W. R., Middleton, P., and Chang, J. S.: The second generation Regional Acid Deposition Model chemical mechanism for regional air quality modeling, J. Geophys. Res., 95, 1634316367, doi:10.1029/JD095iD10p16343, 1990.

Thornton, D. C., Bandy, A. R., Tu, F. H., Blomquist, B. W., Mitchell, G. M., Nadler, W., and Lenschow, D. H.: Fast airborne sulfur dioxide measurements by Atmospheric Pressure Ionization Mass Spectrometry (APIMS), J. Geophys. Res., 107, 4632, doi:10.1029/2002JD002289, 2002.

Tomlinson, J. M., Li, R., and Collins, D. R.: Physical and chemical properties of the aerosol within the Southeastern Pacific marine boundary layer, J. Geophys. Res., 112, D12211, doi:10.1029/2006JD007771, 2007.

Tyndall, G. S. and Ravishankara, A. R.: Atmospheric oxidation of reduced sulfur species, Int. J. Chem. Kinet., 23, 483-527, doi:10.1002/kin.550230604, 1991.

Twomey, S. A.: The influence of pollution on the shortwave albedo of clouds, J. Atmos. Sci., 34, 1148-1152, doi:10.1175/15200469(1977)034<1149:TIOPOT>2.0.CO;2, 1977.

Uselman, W. M., Levine, S. Z., Chan, W. H., Calvert, J. G., and Shaw, J. H.: Nitrogenous Air Pollutants, Chemical and Biological Implications, chap. A kinetic study of the mechanism of peroxynitric acid formation in irradiated mixtures of chlorine, hydrogen, nitrogen dioxide and nitric oxide in air, Ann Arbor Science Publishers, Ann Arbor, MI, USA, 1979.

Wang, H. and Feingold, G.: Modeling mesoscale cellular structures and drizzle in marine stratocumulus. Part I: Impact of drizzle on the formation and evolution of open cells, J. Atmos. Sci., 66, 3237-3256, doi:10.1175/2009JAS3022.1, 2009.
Wang, H., Skamarock, W. C., and Feingold, G.: Evaluation of scalar advection schemes in the Advanced Research WRF model using large-eddy simulations of aerosol-cloud interactions, Mon. Weather Rev., 137, 2547-2558, doi:10.1175/2009MWR2820.1, 2009.

Wang, H., Feingold, G., Wood, R., and Kazil, J.: Modelling microphysical and meteorological controls on precipitation and cloud cellular structures in Southeast Pacific stratocumulus, Atmos. Chem. Phys., 10, 6347-6362, doi:10.5194/acp-10-6347-2010, 2010.

Warner, J.: A reduction in rainfall associated with smoke from sugar-cane fires - an inadvertent weather modification?, J. Appl. Meteorol., 7, 247-251, doi:10.1175/15200450(1968)007<0247:ARIRAW>2.0.CO;2, 1968.

Wesely, M.: Parameterization of surface resistances to gaseous dry deposition in regional-scale numerical models, Atmos. Environ., 41, 52-63, doi:10.1016/j.atmosenv.2007.10.058, 2007.

Wood, R., Bretherton, C. S., Leon, D., Clarke, A. D., Zuidema, P., Allen, G., and Coe, H.: An aircraft case study of the spatial transition from closed to open mesoscale cellular convection over the Southeast Pacific, Atmos. Chem. Phys. Discuss., 10, 1791117980, doi:10.5194/acpd-10-17911-2010, 2010.

Wood, R., Mechoso, C. R., Bretherton, C. S., Weller, R. A., Huebert, B., Straneo, F., Albrecht, B. A., Coe, H., Allen, G., Vaughan, G., Daum, P., Fairall, C., Chand, D., Gallardo Klenner, L., Garreaud, R., Grados, C., Covert, D. S., Bates, T. S., Krejci, R., Russell, L. M., de Szoeke, S., Brewer, A., Yuter, S. E., Springston, S. R., Chaigneau, A., Toniazzo, T., Minnis, P., Palikonda, R., Abel, S. J., Brown, W. O. J., Williams, S., Fochesatto, J., Brioude, J., and Bower, K. N.: The VAMOS Ocean-Cloud-Atmosphere-Land Study Regional Experiment (VOCALS-REx): goals, platforms, and field operations, Atmos. Chem. Phys., 11, 627-654, doi:10.5194/acp-11-6272011, 2011.

Yang, M., Blomquist, B. W., and Huebert, B. J.: Constraining the concentration of the hydroxyl radical in a stratocumulus-topped marine boundary layer from sea-to-air eddy covariance flux measurements of dimethylsulfide, Atmos. Chem. Phys., 9, 92259236, doi:10.5194/acp-9-9225-2009, 2009.

Yang, M., Huebert, B. J., Blomquist, B. W., Howell, S. G., Shank, L. M., McNaughton, C. S., Clarke, A. D., Hawkins, L. N., Russell, L. M., Covert, D. S., Coffman, D. J., Bates, T. S., Quinn, P. K., Zagorac, N., Bandy, A. R., de Szoeke, S. P., Zuidema, P. D., Tucker, S. C., Brewer, W. A., Benedict, K. B., and Collett, J. L.: Atmospheric sulfur cycling in the southeastern Pacific longitudinal distribution, vertical profile, and diel variability observed during VOCALS-REx, Atmos. Chem. Phys., 11, 50795097, doi:10.5194/acp-11-5079-2011, 2011.

Yvon, S. A., Plane, J. M. C., Nien, C., Cooper, D. J., and Saltzman, E. S.: Interaction between nitrogen and sulfur cycles in the polluted marine boundary layer, J. Geophys. Res., 101, 13791386, doi:10.1029/95JD02905, 1996. 